Detrick, R., Honnorez, J., Bryan, W. B., Juteau, T., et al., 1990

Proceedings of the Ocean Drilling Program, Scientific Results, Vol. 106/109

\title{
11. COMPLEX ZONING IN PLAGIOCLASE FELDSPARS FROM ODP SITE $648^{1}$
}

\author{
Peter S. Meyer ${ }^{2}$ and Tsugio Shibata ${ }^{3}$
}

\begin{abstract}
ODP Legs 106 and 109 drilled zero-age crust at Site 648 on the axis of the Mid-Atlantic Ridge and recovered sparsely to moderately phyric but chemically homogeneous basalt. Plagioclase phenocrysts in Site 648 basalts exhibit a variety of zoning patterns and compositions including: (1) tabular $\left(\mathrm{An}_{84}\right)$ cores mantled by more sodic zones $\left(A n_{80}\right.$ and $\left.A n_{75}\right)$, (2) tabular $\left(A n_{80}\right)$ cores mantled by narrow $\left(A n_{84}\right.$ and $\left.A n_{75}\right)$ zones, (3) skeletal cores $\left(A n_{80-78}\right)$ enclosing sodic $\left(A n_{75}\right)$ patches, and (4) rounded cores $\left(A n_{75}\right)$ surrounded by skeletal $\left(A n_{80-78}\right)$ mantles. Backscattered electron images have been used to define zone morphologies in 28 crystals; major element compositions of the zones have been determined by electron microprobe; and $\mathrm{Mg}, \mathrm{K}, \mathrm{Ti}, \mathrm{Fe}$, and $\mathrm{Sr}$ concentrations have been determined by ion microprobe. Equilibrium partitioning of minor and trace elements between crystals and liquids occurred during stable growth of tabular cores and inner rims. Disequilibrium partitioning occurred during rapid growth of crystal rims, resulting in enrichment of incompatible trace and minor elements, and during growth of calcic zones with skeletal and acicular morphology, resulting in enrichment of $\mathrm{Fe}$ and $\mathrm{Sr}$ and depletion of $\mathrm{Mg}, \mathrm{K}$, and Ti. Crystal/liquid partition coefficients estimated from the composition of inner rims and glass are $\mathrm{D}_{\mathrm{Mg}}=0.03$, $\mathrm{D}_{\mathrm{K}}=0.15, \mathrm{D}_{\mathrm{Ti}}=0.028, \mathrm{D}_{\mathrm{Fe}}=0.05$, and $\mathrm{D}_{\mathrm{Sr}}=1.82$. Using these partition coefficients, we have calculated the composition of primitive liquid in equilibrium with phenocryst cores. The estimated liquid composition is similar to primitive basalt compositions from the Kane Fracture Zone except for a much higher $\mathrm{Ca} /(\mathrm{Ca}+\mathrm{Na})$ ratio which resembles values for MAR plume basalts. The diversity in plagioclase morphologies and compositions is explained by mixing of melts at different stages of evolution and stored in separated but interconnected reservoirs, as previously suggested by Kuo and Kirkpatrick (1982).
\end{abstract}

\section{INTRODUCTION}

Site 648 is located on the summit plateau of Serocki volcano, a small edifice on the axis of the Mid-Atlantic Ridge (MAR) just south of the Kane Fracture Zone $\left(28^{\circ} \mathrm{N}\right)$. Drilling on Legs 106 and 109 penetrated $50 \mathrm{~m}$ of sparsely to moderately phyric basalt. The cored basalt is chemically homogeneous (Detrick, Honnorez, Bryan, Juteau, et al., 1988) and represents one eruptive unit with several cooling units. Plagioclase phenocrysts in Site 648 basalts range in size from $<1$ to $5 \mathrm{~mm}$ (Fig. 1), vary in modal abundance from 1 to 10 volume percent, and exhibit a variety of zoning patterns even within individual thin sections.

Normal concentric, reverse, oscillatory, patchy, and sector zoning are all apparent, even in individual thin sections. Crystal outlines and zone morphologies range from euhedral to rounded and embayed to skeletal. Plagioclase compositions range from $\mathrm{An}_{85.2}$ in the cores and mantles of some phenocrysts to $\mathrm{An}_{80}$ on the outer rims of crystals and zones bordering melt inclusions. Such diversity in zoning patterns and compositions is a common feature of MAR basalts (e.g., Muir and Tilley, 1964; Bryan and Moore, 1977 Dungan et al., 1978; Natland, 1979a; Shibata et al., 1979; Sigurdsson, 1981 Kuo and Kirkpatrick, 1982) and has been interpreted as evidence of mixing of two or more magmas. Magma mixing is a direct consequence of the episodic nature and intermittent replenishing of magmatic systems at mid-ocean ridges (e.g., Dungan et al., 1978).

The purpose of this paper is to document zone morphologies with back-scattered electron images, major element vari-

\footnotetext{
${ }^{1}$ Detrick, R., Honnorez, J., Bryan, W. B., Juteau, T., et al., 1990. Proc. ODP, Sci. Results, 106/109: College Station, TX (Ocean Drilling Program).

2 Department of Geology and Geophysics, Woods Hole Oceanographic Institution, Woods Hole, MA 02548.

${ }^{3}$ Faculty of Science, Okayama University, 3-1-1 Tsushimanaka, Okayama 700, Japan.
}

ations with the electron microprobe, and minor and trace element variations with the ion microprobe. We present data on crystal rims that allow us to evaluate crystal/liquid partition coefficients. We also present major and trace element data on phenocryst cores that enable us to characterize the thermal and chemical nature of magmas feeding this part of the MAR. Since plagioclase is neutrally buoyant in basaltic magmas and does not reequilibrate rapidly (Grove et al., 1984); it is an excellent recorder of the pre-eruptive history of magma batches (e.g., Kuo and Kirkpatrick, 1982). Compositional zones record variations in the composition, temperature, and storage depth of magmas as well as variations in volatile pressure and hydraulic pressure.

In the plagioclase crystals from Hole $648 \mathrm{~B}$, minor and trace element concentrations broadly correlate with anorthite content. This is largely due to compositional differences between cores and rims. Deviations from the broad correlations, however, are significant and characteristic of zones that underwent unstable growth, e.g., sector zones, patchy zones, complex mantles, and the outermost rims of crystals. Apparent partition coefficients vary from element to element, those for $\mathrm{Mg}, \mathrm{Fe}$, and $\mathrm{Sr}$ deviating most from equilibrium partition coefficients. Variation in trace element behavior suggests that partitioning is controlled by the kinetics of diffusion and crystal growth in addition to crystal chemistry.

\section{ANALYTICAL TECHNIQUES}

Back-scattered electron images (BEI) of plagioclase crystals were collected on a JEOL 738 Superprobe at Okayama University. These images represent average atomic element maps and depict changes in anorthite content as small as $3 \%$. In these images, lighter grays indicate higher anorthite contents, i.e., higher concentrations of $\mathrm{Ca}$ and $\mathrm{Al}$ compared to $\mathrm{Si}$ and $\mathrm{Na}$. Resolution is enhanced at high magnification so mosaics of high magnification photographs were used to illustrate zoning patterns. BEl's were used as guides for high precision analyses with the electron and ion microprobes.

Major and minor element analyses were carried out on the four-spectrometer JEOL 733 Superprobe at MIT using the Bence and 

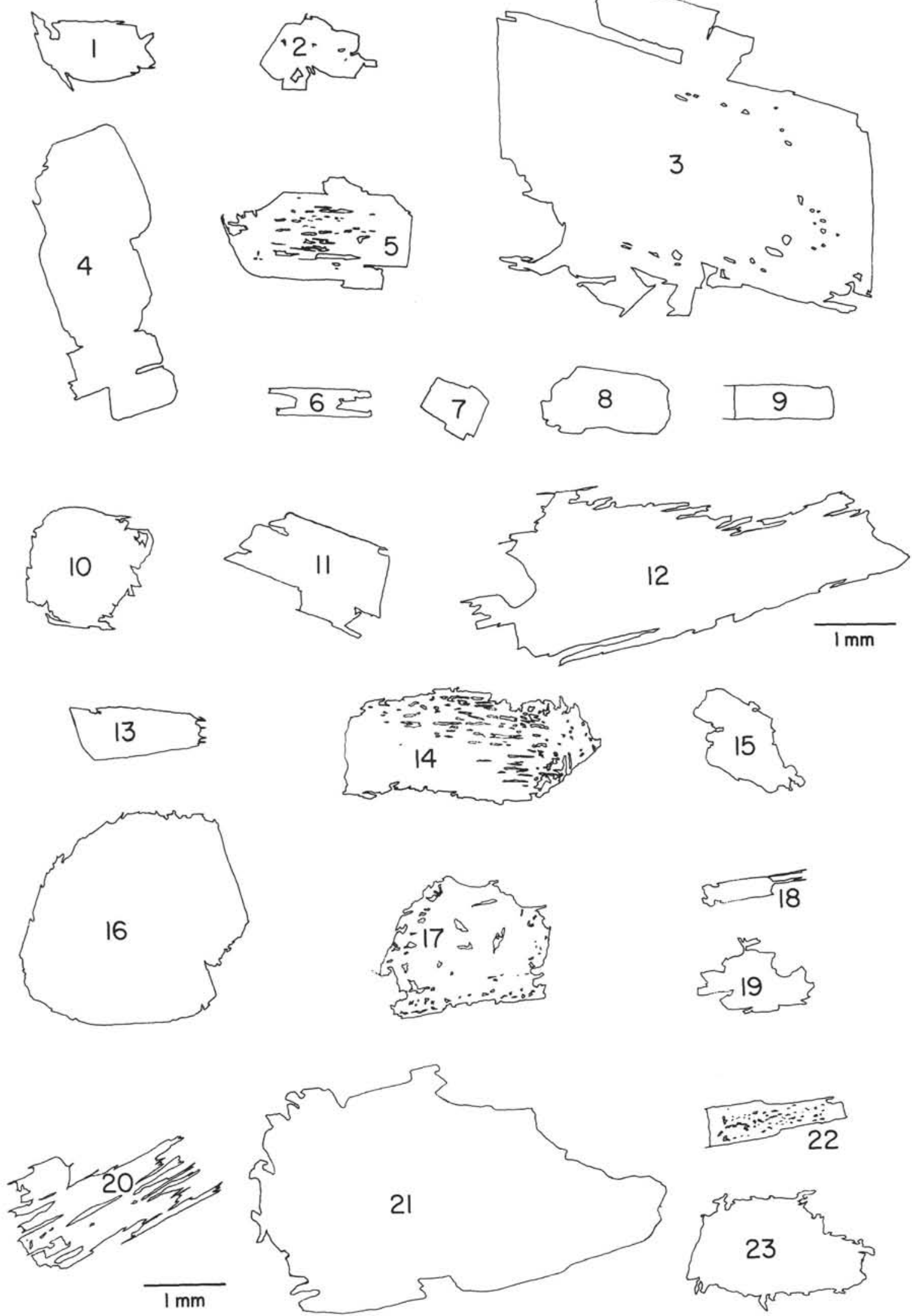

Figure 1. Outlines of plagioclase phenocrysts analyzed in this study. All crystals from Hole $648 \mathrm{~B} .1=1 \mathrm{R}-1,26-29 \mathrm{~cm} ; 2$, $3,4=1 \mathrm{R}-1,118-121 \mathrm{~cm} ; 5,6,7=1 \mathrm{R}-2,37-40 \mathrm{~cm} ; 8=1 \mathrm{R}-2,107-109 \mathrm{~cm} ; 9,10=1 \mathrm{R}-3,87-90 \mathrm{~cm} ; 11,12,19=2 \mathrm{R}-1,12-16$ $\mathrm{cm} ; 13=3 \mathrm{R}-1,3-6 \mathrm{~cm} ; 14,15=3 \mathrm{R}-1,31-34 \mathrm{~cm} ; 16,17,18=3 \mathrm{R}-1,74-77 \mathrm{~cm} ; 20,21,22=6 \mathrm{R}-1,32-37 \mathrm{~cm} ; 23=6 \mathrm{R}-1$, $83-85 \mathrm{~cm}$. 
Albee (1968) matrix corrections with the modifications of Albee and Ray (1970). A focused (1-2- $\mu \mathrm{m}$ spot) $10 \mathrm{nA}$ beam was used for all analyses. For traverses, all elements were counted for $10 \mathrm{~s}$. For individual spot analyses, counting times were increased to up to $40 \mathrm{~s}$ to enhance counting statistics. Standardization was performed on a combination of natural and synthetic standards. A labradorite from Lake County, Oregon, USNM 115900 (Meyer et al., 1974) was used solely as a secondary standard. Representative analyses of plagioclase in Hole 648B basalts are reported in Table 1.

Trace $(\mathrm{K}, \mathrm{Ti}, \mathrm{Sr})$ and minor $(\mathrm{Mg}, \mathrm{Fe})$ element concentrations were determined by secondary ion mass spectrometry (SIMS) on a Cameca IMS $3 \mathrm{f}$ ion microprobe at MIT. Details of this technique and facility have been described elsewhere (Shimizu, 1978; Shimizu and Hart, 1982; Shimizu and le Roex, 1986). In this study, the primary O beam was focused to a spot $10-15 \mu \mathrm{m}$ in diameter. Secondary positive ions were sputtered from sample surfaces and accelerated to $4.41 \mathrm{keV}$. Molecular ion interferences in the mass spectra were minimized using an energy filtering technique; specifically, by reducing the secondary ion accelerating voltage by $90 \mathrm{eV}$. Counting times were $20-30 \mathrm{~s}$ for minor and trace elements and $2-5 \mathrm{~s}$ for major elements. Count rates for the trace elements ranged from 30 to 300 counts/s with backgrounds less than 0.5 counts/s. For each analysis, intensities of ${ }^{23} \mathrm{Na}$, ${ }^{24} \mathrm{Mg},{ }^{27} \mathrm{Al},{ }^{28} \mathrm{Si},{ }^{39} \mathrm{~K},{ }^{40} \mathrm{Ca},{ }^{47} \mathrm{Ti},{ }^{58} \mathrm{Fe}$, and ${ }^{88} \mathrm{Sr}$ were measured five times. Intensities were then corrected for dead-time, background, and isotopic abundances. An average intensity ratio for each element against $\mathrm{Si}$ was calculated by interpolating between each of the five corrected measurements and then averaging the interpolated points. Standard deviations of the intensity ratios ranged from $0.2 \%$ to $0.6 \%$ for major and minor elements and from $1 \%$ to $5 \%$ for trace elements. The beam was allowed to burn into the sample for at least $20 \mathrm{~min}$ prior to measuring at each analysis point. Less time resulted in anomalously high ${ }^{39} \mathrm{~K}$ intensities.

Elemental concentrations were determined using working curves plotted on concentration vs. intensity ratio diagrams. Two standards with well-known compositions were used; a labradorite $\left(\mathrm{An}_{69.2}\right)$ from Lake County, Oregon, and an anorthitic plagioclase $\left(\mathrm{An}_{89.1}\right)$ from Pacaya volcano. Previous SIMS studies (Ray, 1980; Shimizu, 1978; Shimizu and Hart, 1982) have generally revealed linear relationships between trace element concentrations and intensity ratios. In this study, however, simple regressions based on the two standards did not pass through the origin, leading to significant errors for the lower concentrations of $\mathrm{Sr}$ and $\mathrm{K}$. For this reason, logarithmic curves were used to calculate $\mathrm{K}$ and $\mathrm{Sr}$ concentrations. Over the course of the study, the standards were analyzed 15 times with the following precision; $\pm 4 \%$ for $\mathrm{Mg}, \pm 10 \%$ for $\mathrm{K}$, and $\pm 7 \%-8 \%$ for $\mathrm{Ti}, \mathrm{Fe}$, and $\mathrm{Sr}$. These estimates are based on the lower of the two standard concentrations, i.e., $400 \mathrm{ppm}$ for $\mathrm{Mg}, 145 \mathrm{ppm}$ for $\mathrm{K}, 185 \mathrm{ppm}$ for Ti, 3950 $\mathrm{ppm}$ for $\mathrm{Fe}$, and $580 \mathrm{ppm}$ for $\mathrm{Sr}$. These concentration levels are similar to those in the Hole 648 plagioclases for $\mathrm{Ti}, \mathrm{K}$, and $\mathrm{Fe}$ but higher than the $\mathrm{Sr}$ concentrations (100-200 ppm) and much lower than $\mathrm{Mg}$ concentrations (1000-1400 ppm).

Representative minor and trace element concentrations determined by SIMS are reported in Table 2 . Similar spots analyzed by both electron microprobe and ion microprobe yielded similar results for $\mathrm{Mg}$ and $\mathrm{Fe}$ (Fig. 2); the short counting times by electron microprobe resulted in poorer precision $( \pm 20 \%)$. Low $\mathrm{K}$ concentrations ( 50 $\mathrm{ppm}$ ) determined by ion microprobe agree well with concentrations determined by 500 -s counts on the electron microprobe.

\section{PETROGRAPHY AND COMPOSITION OF HOLE 648B LAVA}

Hole $648 \mathrm{~B}$ basalts are sparsely to moderately plagioclaseolivine phyric with $1 \%-10 \%$ plagioclase and $0 \%-5 \%$ olivine phenocrysts (Detrick, Honnorez, Bryan, Juteau, et al., 1988). Plagioclase occurs as isolated crystals, in plagioclase glomerocrysts, and in glomerocrysts with olivine. Plagioclase phenocrysts range in size from 1 to $5 \mathrm{~mm}$ (Fig. 1) while olivine phenocrysts range in size from 0.1 to $0.8 \mathrm{~mm}$. Vesicles are generally sparse $(<1 \%-2 \%)$ but in rare cases make up $10 \%$ of the basalt (Detrick, Honnorez, Bryan, Juteau, et al., 1988). They range in size from 0.1 to $2.0 \mathrm{~mm}$, and are generally round and empty. Groundmass textures range from subvariolitic to variolitic (spherulitic) in cryptocrystalline samples and from intersertal to intergranular to subophitic in fine-grained samples.

The average composition of olivine phenocryst cores is $\mathrm{Fo}_{84.5}$ (Table 3) yielding an olivine/glass $\mathrm{K}_{\mathrm{D}}=0.27\left(\mathrm{~K}_{\mathrm{D}}=\right.$ $\left(\mathrm{X}_{\mathrm{Fe}} / \mathrm{X}_{\mathrm{Mg}}\right)^{\text {ol }} \times\left(\mathrm{X}_{\mathrm{Mg}} / \mathrm{X}_{\mathrm{Fe}}\right)^{\text {glass }}, \mathrm{Fe}^{2+}$ in the glass $=0.9 \times \mathrm{Fe}$ total). This agrees with the equilibrium value found by Sigurdsson (1981) for MORB olivine-glass pairs. Olivine phenocrysts are normally zoned to $\mathrm{Fo}_{84.0}$. The compositional range of plagioclase phenocrysts $\left(\mathrm{An}_{85-60}\right)$, however, suggests that most plagioclase crystals were not in equilibrium with surrounding melt. Based on 1-atmosphere experiments (Grove and Bryan, 1983; Grove et al., this volume), the equilibrium plagioclase composition is $\mathrm{An}_{70-65}$.

Chemical data on Hole 648B basalts (Detrick, Honnorez, Bryan, Juteau, et al., 1988) indicate only minor variations in the drilled basalt. Glasses have an average $\mathrm{Mg} /\left(\mathrm{Mg}+\mathrm{Fe}^{2+}\right)$ ratio of 0.600 , assuming $\mathrm{Fe}^{2+} /\left(\mathrm{Fe}^{2+}+\mathrm{Fe}^{3+}\right)=0.9$, and an average $\mathrm{TiO}_{2}$ content of $1.77 \mathrm{wt} \%$ compared to the slightly less evolved bulk rock compositions that have an average $\mathrm{Mg} / \mathrm{Mg}$ $+\mathrm{Fe}^{2+}$ ) ratio of 0.606 and $\mathrm{TiO}_{2}$ content of $1.68 \mathrm{wt} \%$ (Table 4). The average loss-on-ignition data suggests a total volatile content of $0.23 \mathrm{wt} \%$.

\section{ZONE MORPHOLOGIES AND COMPOSITIONS OF PLAGIOCLASE PHENOCRYSTS}

Hole 648B plagioclase crystals can be divided into three main types based on the morphology of compositional zones: (1) tabular crystals with prismatic, homogeneous cores; (2) crystals exhibiting skeletal outlines and/or skeletal internal zones that are characterized by distinct patchy zoning or sector zoning; and (3) tabular crystals with rounded and embayed cores that are more calcic than surrounding mantles and rims. Compositional zoning in 23 representative crystals is discussed below.

\section{Tabular Crystals with Prismatic Inner Zones}

This crystal type is represented by crystals $2,3,4,8,10$, 13, 15, 16, 17, and 21. Crystal 3 (Fig. 3) has a homogeneous $\left(\mathrm{An}_{77.7-76.2}\right)$ but irregularly shaped core marked by an abundance of small $(5 \mu \mathrm{m})$ melt inclusions. The core is surrounded by a prismatic, homogeneous $\left(\mathrm{An}_{81-79}\right)$ zone (mantle) with larger melt inclusions that is in turn surrounded by a normally zoned $\left(\mathrm{An}_{72-60.6}\right)$ rim. Except for the outer rim, each zone appears to be homogeneous with respect to trace elements. K, $\mathrm{Ti}$, and $\mathrm{Fe}$ increase systematically from core to rim (Table 2), in contrast to the reversal in anorthite content observed in the mantle. $\mathrm{Mg}$ decreases systematically from core to inner rim and then increases in parts of the outer rim. The compositional variations in crystal 3 may be explained by magma mixing, the core having crystallized from one magma and the mantle and rim from a second one. Alternatively these variations may reflect progressive differentiation of a magmatic liquid during ascent from depth to a shallow level magma chamber. The reversal in anorthite content is then attributed to a drop in pressure (see Bender et al., 1978, and Grove et al., this volume for relevant experimental results). The sodic nature of the rim, a common feature of many crystals, undoubtedly reflects post-eruptive crystal growth in cooling unit interiors.

Crystal 4 (Fig. 4) exhibits a slightly different zoning pattern. The crystal is actually a glomerocryst composed of at least three separate crystals. Again the core is fairly homogeneous in composition $\left(\mathrm{An}_{85-82}\right)$ although there appears to be a small, distinctly more sodic inner core $\left(\mathrm{An}_{78}\right)$. The calcic core has low abundances of $\mathrm{K}(50 \mathrm{ppm}), \mathrm{Ti}(165 \mathrm{ppm}), \mathrm{Fe}(3040$ $\mathrm{ppm})$, and $\mathrm{Sr}(115 \mathrm{ppm})$ and likely crystallized from a more primitive basaltic melt than the one represented by the $648 \mathrm{~B}$ glass. Other factors could have prompted the crystallization of 
Table 1. Representative electron microprobe analyses of plagioclase crystals in Hole 648B lava.

\begin{tabular}{|c|c|c|c|c|c|c|c|c|c|c|c|c|c|c|}
\hline & 2 & 2 & 2 & 3 & 3 & 3 & 3 & 3 & 4 & 4 & 4 & 5 & 5 & 5 \\
\hline & Core & Osc. Zone & Rim & Core & Mantle $N$ & $\begin{array}{l}\text { Near Mell } \\
\text { Inclu. }\end{array}$ & $\begin{array}{l}\text { Inner } \\
\text { Rim }\end{array}$ & Rim & Core & $\begin{array}{l}\text { Narrow } \\
\text { Mantle }\end{array}$ & $\begin{array}{l}\text { Inner } \\
\text { Rim }\end{array}$ & $\begin{array}{c}\text { Core } \\
\text { Zone } 1\end{array}$ & $\begin{array}{c}\text { Core } \\
\text { Zone } 2 \\
\end{array}$ & $\begin{array}{l}\text { Near Mel } \\
\text { Inclu. }\end{array}$ \\
\hline $\mathrm{SiO} 2$ & 51.04 & 49.54 & 53.85 & 49.27 & 48.45 & 53.26 & 50.09 & 51.52 & 47.29 & 47.27 & 50.91 & 48.08 & 50.88 & 54.18 \\
\hline $\mathrm{Al} 2 \mathrm{O} 3$ & 30.78 & 32.11 & 28.23 & 32.52 & 32.97 & 29.34 & 31.32 & 30.09 & 33.50 & 33.70 & 30.95 & 32.94 & 30.73 & 28.33 \\
\hline $\mathrm{F} \oplus \mathrm{O}$ & 0.40 & 0.39 & 1.23 & 0.29 & 0.42 & 0.49 & 0.40 & 0.72 & 0.29 & 0.36 & 0.45 & 0.44 & 0.43 & 0.75 \\
\hline MgO & 0.23 & 0.22 & 0.44 & 0.24 & 0.20 & 0.32 & 0.23 & 0.27 & 0.22 & 0.20 & 0.22 & 0.15 & 0.23 & 0.26 \\
\hline $\mathrm{CaO}$ & 13.88 & 15.16 & 12.09 & 15.42 & 15.77 & 12.47 & 14.61 & 13.35 & 17.20 & 16.85 & 14.30 & 16.50 & 14.39 & 11.61 \\
\hline $\mathrm{Na2O}$ & 3.42 & 2.71 & 4.34 & 2.52 & 2.18 & 4.43 & 3.10 & 3.68 & 1.66 & 1.76 & 3.31 & 1.94 & 3.16 & 4.68 \\
\hline $\mathrm{K} 2 \mathrm{O}$ & 0.02 & 0.00 & 0.04 & 0.00 & 0.00 & 0.01 & 0.00 & 0.02 & 0.00 & 0.00 & 0.03 & 0.00 & 0.03 & 0.06 \\
\hline Sum & 99.77 & 100.13 & 100.21 & 100.77 & 99.99 & 100.32 & 99.75 & 99.65 & 100.16 & 100.14 & 100.17 & 100.05 & 99.85 & 99.8 \\
\hline $\mathrm{Si}$ & 3287 & 2.2599 & 4412 & 2445 & 2.2167 & 4080 & 2.2915 & 2.3535 & 2.1693 & 2.1674 & 2.3169 & 2.2037 & 2.3220 & 2.4562 \\
\hline Al & 6546 & 1.7261 & 1.5082 & 1.7460 & 1.7778 & 1.5632 & 1.6883 & 1.6201 & 1.8108 & 1.8211 & 1.6597 & 1.7792 & 1.6528 & 1.5133 \\
\hline $\mathrm{Fe}$ & 0.0151 & 0.0149 & 0.0465 & 0.0112 & 0.0160 & 0.0186 & 0.0151 & 0.0276 & 0.0111 & 0.0137 & 0.0171 & 0.0170 & 0.0164 & 0.0283 \\
\hline Mg & 0.0155 & 0.0152 & 0.0297 & 0.0165 & 0.0137 & 0.0218 & 0.0157 & 0.0183 & 0.0150 & 0.0136 & 0.0152 & 0.0102 & 0.0159 & 0.0178 \\
\hline $\mathrm{Ca}$ & 0.6782 & 0.7410 & 0.5870 & 0.7526 & 0.7731 & 0.6039 & 0.7159 & 0.6532 & 0.8452 & 0.8276 & 0.6970 & 0.8100 & 0.7036 & 0.5639 \\
\hline $\mathrm{Na}$ & 0.3023 & 0.2396 & 0.3815 & 0.2229 & 0.1935 & 0.3884 & 0.2752 & 0.3258 & 0.1473 & 0.1567 & 0.2922 & 0.1727 & 0.2795 & 0.4115 \\
\hline $\mathrm{K}$ & 0.0010 & 0.0000 & 0.0022 & 0.0000 & 0.0000 & 0.0008 & 0.0000 & 0.0011 & 0.0000 & 0.0000 & 0.0019 & 0.0000 & 0.0016 & 0.0032 \\
\hline Sum & 4.9954 & 4.9965 & 4.9962 & 4.9936 & 4.9908 & 5.0047 & 5.0016 & 4.9995 & 4.9987 & 5.0001 & 5.0000 & 4.9928 & 4.9918 & 4.9942 \\
\hline An & 69.1 & 76.6 & 60.5 & 77.1 & 80.0 & 60.8 & 72.2 & 66.7 & 85.2 & 84.1 & 70.3 & 82.4 & 71.5 & 57.6 \\
\hline
\end{tabular}

Table 1 (continued).

\begin{tabular}{|c|c|c|c|c|c|c|c|c|c|c|c|c|c|}
\hline 16 & 16 & 16 & 17 & 17 & 17 & 18 & 18 & 19 & 19 & 19 & 20 & 20 & 20 \\
\hline Core & $\begin{array}{l}\text { Narrow } \\
\text { Mantle }\end{array}$ & Rim & Core & Core & Rim & $\begin{array}{l}\text { Basal } \\
\text { Sector }\end{array}$ & $\begin{array}{l}\text { Prism } \\
\text { Sector }\end{array}$ & $\begin{array}{c}\text { Core } \\
\text { Zone } 1\end{array}$ & $\begin{array}{c}\text { Core } \\
\text { Zone } 2\end{array}$ & Rim & $\begin{array}{c}\text { Core } \\
\text { Zone } 1\end{array}$ & $\begin{array}{c}\text { Core } \\
\text { Zone } 2\end{array}$ & Rim \\
\hline 48.33 & 47.19 & 52.46 & 47.02 & 48.40 & 51.42 & 49.36 & 48.22 & 47.46 & 49.67 & 51.34 & 48.94 & 50.43 & 53.44 \\
\hline 31.91 & 33.51 & 29.53 & 33.27 & 32.61 & 29.99 & 31.91 & 33.08 & 33.44 & 31.68 & 30.62 & 32.46 & 30.90 & 28.63 \\
\hline 0.31 & 0.40 & 0.56 & 0.39 & 0.37 & 0.56 & 0.36 & 0.41 & 0.37 & 0.44 & 0.49 & 0.35 & 0.36 & 0.78 \\
\hline 0.22 & 0.18 & 0.34 & 0.18 & 0.21 & 0.27 & 0.24 & 0.20 & 0.21 & 0.24 & 0.24 & 0.19 & 0.22 & 0.38 \\
\hline 16.50 & 17.02 & 12.96 & 16.42 & 16.33 & 13.63 & 15.35 & 16.01 & 16.23 & 14.56 & 13.97 & 16.23 & 14.83 & 12.63 \\
\hline 2.11 & 1.71 & 3.91 & 1.81 & 2.19 & 3.55 & 2.65 & 2.19 & 2.10 & 2.95 & 3.66 & 2.27 & 3.15 & 4.31 \\
\hline 0.03 & 0.02 & 0.05 & 0.03 & 0.03 & 0.05 & 0.05 & 0.03 & 0.03 & 0.03 & 0.03 & 0.02 & 0.02 & 0.04 \\
\hline 99.47 & 100.03 & 99.81 & 99.12 & 100.14 & 99.47 & 99.92 & 100.14 & 99.84 & 99.57 & 100.35 & 100.46 & 99.91 & 100.21 \\
\hline 2.2306 & 2.1681 & 2.3871 & .1767 & 2.2161 & 2.3530 & 2.2584 & 2.2059 & 2.1806 & 2.2766 & 2.3322 & 2.2317 & 2.3045 & 2.4229 \\
\hline 1.7339 & 1.8141 & 1.5837 & 1.8151 & 1.7598 & 1.6176 & 1.7205 & 1.7835 & 1.8108 & 1.7110 & 1.6394 & 1.7443 & 1.6640 & 1.5299 \\
\hline 0.0120 & 0.0154 & 0.0214 & 0.0150 & 0.0143 & 0.0215 & 0.0137 & 0.0159 & 0.0143 & 0.0167 & 0.0184 & 0.0132 & 0.0138 & 0.0296 \\
\hline 0.0154 & 0.0124 & 0.0229 & 0.0126 & 0.0143 & 0.0185 & 0.0167 & 0.0138 & 0.0146 & 0.0165 & 0.0159 & 0.0128 & 0.0150 & 0.0258 \\
\hline 0.8151 & 0.8378 & 0.6318 & 0.8141 & 0.8011 & 0.6693 & 0.7525 & 0.7849 & 0.7989 & 0.7151 & 0.6799 & 0.7930 & 0.7259 & 0.6133 \\
\hline 0.8190 & 0.1521 & 0.3451 & 0.1625 & 0.1945 & 0.3149 & 0.2354 & 0.1943 & 0.1873 & 0.2619 & 0.3223 & 0.2004 & 0.2792 & 0.3786 \\
\hline 0.0015 & 0.0013 & 0.0029 & 0.0015 & 0.0017 & 0.0032 & 0.0029 & 0.0018 & 0.0015 & 0.0015 & 0.0016 & 0.0012 & 0.0011 & 0.0021 \\
\hline 4.9974 & 5.0012 & 4.9948 & 4.9974 & 5.0018 & 4.9970 & 5.0002 & 5.0000 & 5.0081 & 4.9993 & 5.0098 & 4.9966 & 5.0033 & 5.0022 \\
\hline 81.1 & 84.5 & 64.5 & 83.2 & 80.3 & 67.8 & 75.9 & 80.0 & 80.9 & 73.1 & 67.7 & 79.7 & 72.1 & 61.7 \\
\hline
\end{tabular}

more calcic plagioclase, e.g., a drop in pressure or an increase in volatile concentration (see Smith and Brown, 1988, for a review), but the trace and minor element composition of the calcic plagioclase suggests a change in liquid composition.

Crystal 4 has a complex mantle around its core with discordant oscillatory zoning. Trace and minor element variations from core to rim across the mantle are shown in Figure 5. $\mathrm{Mg}, \mathrm{K}$, and $\mathrm{Ti}$ show an inverse correlation with anorthite content, the $\mathrm{Mg}$ traverse being an almost perfect mirror image of the anorthite content. In contrast, $\mathrm{Fe}$ and $\mathrm{Sr}$ increase continuously from core to rim. These compositional variations appear to reflect a change in crystallization kinetics (discussed further below).

Prismatic calcic $\left(\mathrm{An}_{84-80}\right)$ cores are also observed in smaller phenocrysts, e.g., crystal 15 which consists of two 1-mm-long crystals that grew together shortly after their cores formed.
Mantles around these cores are oscillatory zoned from $\mathrm{An}_{75}$ to $\mathrm{An}_{70}$ and rims are normally zoned to $\mathrm{An}_{66}$. The most calcic region in many phenocrysts, however, occurs as a narrow zone or group of oscillatory zones between core and rim. Crystals 8 and 16 (Fig. 6) are good examples. These crystals have homogeneous cores $\left(\mathrm{An}_{80-78}\right)$, narrow calcic mantles $\left(A n_{85-83}\right)$, and normally zoned rims $\left(A n_{75-60}\right)$. This establishes that growth of $A_{80}$ plagioclase preceded growth of $A_{84}$ plagioclase in many crystals.

\section{Crystals Exhibiting Skeletal Morphologies and Patchy Zoning}

Crystals 5, 6, 12, 14, 18, 19, 20, 22, and 23 exhibit skeletal internal morphologies and patchy zoning (Figs. 7-11) or sector zoning (Fig. 12). Crystals 6, 12, and 20 also have skeletal margins. In most cases, patchy zoning is associated with the 
Table 1 (continued).

\begin{tabular}{|c|c|c|c|c|c|c|c|c|c|c|c|c|c|c|}
\hline 5 & 11 & 11 & 12 & 12 & 12 & 13 & 13 & 13 & 14 & 14 & 14 & 15 & 15 & 15 \\
\hline Rim & Core & Mantle & $\begin{array}{c}\text { Core } \\
\text { Zone } 1\end{array}$ & $\begin{array}{c}\text { Core } \\
\text { Zone 2 }\end{array}$ & Rim & Core & $\begin{array}{l}\text { Inner } \\
\text { Rim }\end{array}$ & Rim & Core & $\begin{array}{l}\text { Skeletal } \\
\text { Margin }\end{array}$ & Rim & Core & Core & Rim \\
\hline 53.12 & 47.56 & 50.40 & 47.70 & 51.20 & 53.35 & 48.64 & 50.27 & 53.67 & 49.34 & 48.19 & 51.93 & 47.51 & 48.74 & 52.56 \\
\hline 28.65 & 32.63 & 31.11 & 33.01 & 30.74 & 28.78 & 31.86 & 30.84 & 27.94 & 32.18 & 32.86 & 30.12 & 33.53 & 32.85 & 29.72 \\
\hline 0.93 & 0.39 & 0.47 & 0.34 & 0.34 & 0.93 & 0.42 & 0.49 & 0.77 & 0.41 & 0.49 & 0.61 & 0.32 & 0.38 & 0.56 \\
\hline 0.43 & 0.20 & 0.23 & 0.16 & 0.24 & 0.41 & 0.14 & 0.22 & 0.26 & 0.19 & 0.20 & 0.26 & 0.18 & 0.21 & 0.25 \\
\hline 12.80 & 16.43 & 14.71 & 16.89 & 14.18 & 12.58 & 15.71 & 14.66 & 12.20 & 15.10 & 15.92 & 13.18 & 17.18 & 16.39 & 13.47 \\
\hline 4.05 & 1.96 & 3.04 & 1.90 & 3.28 & 4.19 & 2.35 & 2.94 & 4.41 & 2.64 & 2.11 & 3.74 & 1.81 & 2.25 & 3.76 \\
\hline 0.04 & 0.00 & 0.02 & 0.00 & 0.04 & 0.05 & 0.02 & 0.03 & 0.05 & 0.02 & 0.02 & 0.04 & 0.00 & 0.02 & 0.04 \\
\hline 100.02 & 99.17 & 99.98 & 100.00 & 100.02 & 100.29 & 99.14 & 99.45 & 99.30 & 99.88 & 99.79 & 99.88 & 100.53 & 100.83 & 100.37 \\
\hline 2.4151 & 2.2001 & 2.3006 & .1903 & 2.3302 & 2.4176 & .2454 & 2.3065 & 2.4513 & 2.2560 & 2.2117 & 2.3633 & 2.1720 & 2.2162 & 2.3809 \\
\hline 1.5348 & 1.7789 & 1.6737 & 1.7864 & 1.6486 & 1.5368 & 1.7335 & 1.6673 & 1.5042 & 1.7340 & 1.7777 & 1.6155 & 1.8066 & 1.7605 & 1.5866 \\
\hline 0.0354 & 0.0152 & 0.0179 & 0.0130 & 0.0130 & 0.0354 & 0.0162 & 0.0186 & 0.0294 & 0.0158 & 0.0187 & 0.0233 & 0.0121 & 0.0143 & 0.0214 \\
\hline 0.0289 & 0.0137 & 0.0159 & 0.0110 & 0.0160 & 0.0276 & 0.0100 & 0.0149 & 0.0180 & 0.0132 & 0.0134 & 0.0179 & 0.0123 & 0.0142 & 0.0169 \\
\hline 0.6233 & 0.8143 & 0.7194 & 0.8308 & 0.6914 & 0.6107 & 0.7771 & 0.7205 & 0.5968 & 0.7398 & 0.7831 & 0.6428 & 0.8413 & 0.7982 & 0.6534 \\
\hline 0.3571 & 0.1762 & 0.2687 & 0.1695 & 0.2896 & 0.3682 & 0.2099 & 0.2616 & 0.3905 & 0.2341 & 0.1878 & 0.3299 & 0.1604 & 0.1987 & 0.3303 \\
\hline 0.0021 & 0.0000 & 0.0010 & 0.0000 & 0.0024 & 0.0029 & 0.0009 & 0.0017 & 0.0029 & 0.0013 & 0.0012 & 0.0022 & 0.0000 & 0.0010 & 0.0022 \\
\hline 4.9968 & 4.9982 & 4.9971 & 5.0009 & 4.9912 & 4.9992 & 4.9930 & 4.9911 & 4.9930 & 4.9943 & 4.9936 & 4.9947 & 5.0046 & 5.0031 & 4.9917 \\
\hline 63.4 & 82.2 & 72.7 & 83.1 & 70.3 & 62.2 & 78.7 & 73.2 & 60.3 & 75.9 & 80.6 & 65.9 & 84.0 & 80.0 & 66.3 \\
\hline
\end{tabular}

\begin{tabular}{rrrrrr}
\multicolumn{1}{c}{22} & \multicolumn{1}{c}{22} & \multicolumn{1}{c}{23} & \multicolumn{1}{c}{23} & \multicolumn{1}{c}{23} & \multicolumn{1}{c}{23} \\
\hline $\begin{array}{c}\text { Core } \\
\text { Zone 1 }\end{array}$ & $\begin{array}{c}\text { Core } \\
\text { Zone } 2\end{array}$ & Core & Mantle & $\begin{array}{c}\text { Inner } \\
\text { Rim }\end{array}$ & Rim \\
\hline 48.05 & 50.00 & 48.18 & 49.15 & 51.02 & 51.94 \\
32.94 & 31.39 & 32.93 & 32.09 & 30.73 & 30.08 \\
0.40 & 0.50 & 0.21 & 0.42 & 0.50 & 0.62 \\
0.16 & 0.22 & 0.19 & 0.21 & 0.20 & 0.24 \\
16.21 & 15.19 & 16.68 & 15.60 & 14.52 & 13.69 \\
2.01 & 2.73 & 1.90 & 2.53 & 3.28 & 3.57 \\
0.02 & 0.00 & 0.00 & 0.01 & 0.03 & 0.05 \\
& & & & & \\
99.79 & 100.03 & 100.09 & 100.01 & 100.28 & 100.20 \\
& & & & & \\
2.2062 & 2.2839 & 2.2055 & 2.2484 & 2.3212 & 2.3596 \\
1.7823 & 1.6894 & 1.7769 & 1.7302 & 1.6477 & 1.6104 \\
0.0155 & 0.0192 & 0.0082 & 0.0161 & 0.0191 & 0.0237 \\
0.0108 & 0.0146 & 0.0128 & 0.0144 & 0.0136 & 0.0163 \\
0.7972 & 0.7434 & 0.8181 & 0.7645 & 0.7078 & 0.6663 \\
0.1790 & 0.2413 & 0.1686 & 0.2244 & 0.2890 & 0.3143 \\
0.0014 & 0.0000 & 0.0000 & 0.0070 & 0.0016 & 0.0030 \\
& & & & & \\
4.9925 & 4.9918 & 4.9900 & 4.9987 & 4.9999 & 4.9935 \\
81.5 & 75.5 & 82.9 & 77.3 & 70.9 & 67.7
\end{tabular}

occurrence of melt inclusions that are elongated parallel to the crystallographic c-axis, e.g., crystals $5,14,19$, and 20. Patchy zones commonly have rectilinear outlines and are aligned parallel to the melt inclusions.

Figure 7 illustrates the compositional variations in crystal 5. The core consists of a skeletal homogeneous $\left(\mathrm{An}_{82-80}\right)$ zone which surrounds patches that are generally zoned from $\mathrm{An}_{77}$ to $\mathrm{An}_{70}$. Near melt inclusions, patches are zoned to at least $\mathrm{An}_{57.6}$ indicating continued crystal growth after inclusions were trapped. The rim which forms a euhedral overgrowth around the skeletal core is normally zoned from $A n_{71}$ to $\mathrm{An}_{63.4}$. Compositional variations in crystal 19 (Fig. 8) are similar to those described for crystal 7 . The microprobe traverse in Figure 8 shows a baseline composition of $\mathrm{An}_{82-80}$ for the skeletal core and infilling patches of $\mathrm{An}_{75}$ that are zoned to
$\mathrm{An}_{63}$ near melt inclusions. The rim is normally zoned from $A n_{75}$ to $A n_{55}$ with several oscillations back to $A n_{75}$.

Crystal 22 (Fig. 9) shows patchy zoning that is more curvilinear than that observed in crystals 5 and 19. Compositions, however, are similar with a skeletal calcic core $\left(\mathrm{An}_{82-80}\right)$ enclosing patches that vary from $A n_{75}$ to $A n_{70}$. Ion microprobe analyses indicate that the sodic patches are enriched in $\mathrm{Mg}, \mathrm{K}$, $\mathrm{Ti}$, and $\mathrm{Fe}$ and have comparable $\mathrm{Sr}$ relative to the skeletal core (Table 2).

Crystal 14 also has a skeletal zone with an average composition of $A n_{80}$ (Table 1), but unlike crystals 5, 19, and 22, the skeletal zone surrounds an elongate but rounded core. The core is distinctly more sodic $\left(A n_{75}\right)$ than the skeletal margin. The morphology and composition of this crystal suggest resorption of the core followed by skeletal growth.

Crystal 20 (Fig. 10) has a skeletal outline that partially encloses fine-grained groundmass. The interior of this crystal is composed of needle-like zones that have a composition of $\mathrm{An}_{80-78}$ and broader zones that are zoned from $\mathrm{An}_{75}$ to $\mathrm{An}_{61.4}$, the more sodic compositions being associated with rims and areas bordering melt inclusions. Figure 11 shows the results of an ion microprobe traverse across one of the calcic needles. Note that the $10-\mu \mathrm{m}$-thick needle is relatively homogeneous, even with respect to trace element concentrations, and also note the sharp compositional break with neighboring zones. Like the skeletal cores of other crystals, the calcic needle is depleted in $\mathrm{Mg}, \mathrm{K}$, and $\mathrm{Ti}$ relative to the surrounding zones, but in contrast to the other crystals, the needle is enriched in $\mathrm{Fe}$. The traverse also depicts a compositional spike in the inner sodic zone that is characterized by enrichments in $\mathrm{Mg}$, $\mathrm{K}, \mathrm{Ti}, \mathrm{Fe}$, and a low anorthite content, reflecting the proximity of a melt inclusion.

Well-developed sector zoning is observed in crystals 6 and 18 (Fig. 12). In both crystals, the prism (010) sector is more calcic $\left(\mathrm{An}_{80-77}\right)$ than the basal $(001)$ sector $\left(\mathrm{An}_{75-70}\right)$, consistent with the findings of Bryan (1974) for sector zoned plagioclase crystals in other submarine pillow basalts and in plagioclase grown experimentally (Lofgren, 1980). The prism sector in crystal 6 is normally zoned and both crystals have narrow sodic $\left(\mathrm{An}_{84-80}\right)$ rims. Figure 13 shows variations in An content, $\mathrm{Ti}$, and $\mathrm{Fe}$ in a traverse across crystal 18 . The calcic prism 
Table 2. Representative ion microprobe analyses of Hole 648B plagioclase.

\begin{tabular}{|c|c|c|c|c|c|c|c|}
\hline Crystal \# & Zone & $\begin{array}{c}\text { An } \\
\text { Content } \\
\end{array}$ & $\begin{array}{l}\mathrm{Mg} \\
\mathrm{ppm}\end{array}$ & $\underset{\mathrm{ppm}}{\mathrm{K}}$ & $\begin{array}{c}\mathrm{Ti} \\
\mathrm{ppm}\end{array}$ & $\begin{array}{l}\mathrm{Fe} \\
\mathrm{ppm}\end{array}$ & $\begin{array}{c}\mathrm{Sr} \\
\mathrm{ppm}\end{array}$ \\
\hline 3 & Core & 76.9 & 1320 & 105 & 115 & 3540 & 160 \\
\hline 3 & Mantle & 80.1 & 1250 & 130 & 180 & 3675 & 185 \\
\hline 3 & Inner Rim & 71.5 & 1210 & 160 & 270 & 3990 & 190 \\
\hline 3 & Rim & 66.7 & 1325 & 180 & 335 & 4140 & 200 \\
\hline 4 & Core & 85.2 & 1310 & 50 & 165 & 3040 & 115 \\
\hline 4 & Inner Mantle & 79.5 & 1490 & 70 & 165 & 3050 & 105 \\
\hline 4 & Outer Mantle & 77.1 & 1350 & 80 & 180 & 3190 & 120 \\
\hline 4 & Outer Mantle & 84.0 & 1015 & 60 & 165 & 3660 & 140 \\
\hline 4 & Inner Rim & 71.2 & 1290 & 140 & 280 & 3730 & 160 \\
\hline 4 & $\operatorname{Rim}$ & 66.4 & 1460 & 150 & 300 & 4000 & 160 \\
\hline 18 & Basal Sector & 73.2 & 1110 & 105 & 215 & 3610 & 210 \\
\hline 18 & Prism Sector & 77.2 & 1050 & 165 & 190 & 3740 & 205 \\
\hline 18 & Rim & 63.6 & 1405 & 195 & 295 & 3930 & 190 \\
\hline 18 & $\operatorname{Rim} 2$ & 67.1 & 1235 & 155 & 280 & 3860 & 185 \\
\hline 20 & Rim & 71.5 & 1320 & 170 & 245 & 4050 & 170 \\
\hline 20 & Calcic Needle & 78.4 & 1175 & 130 & 195 & 4160 & 185 \\
\hline 20 & Inner Sodic Zone & 70.8 & 1270 & 155 & 290 & 4170 & 210 \\
\hline 21 & Core & 75.3 & 1360 & 130 & 165 & 3580 & 190 \\
\hline 22 & Skeletal Core & 79.8 & 1040 & 105 & 175 & 3720 & 180 \\
\hline 22 & Enclosed Patch & 73.0 & 1160 & 140 & 220 & 3750 & 180 \\
\hline 22 & Rim & 68.4 & 1120 & 180 & 300 & 3895 & 210 \\
\hline 24 & Core & 84.0 & 1310 & 70 & 160 & 3140 & 125 \\
\hline 24 & Rim & 67.0 & 1220 & 150 & 260 & 4010 & 200 \\
\hline 25 & Core & 82.0 & 1440 & 100 & 210 & 3400 & 175 \\
\hline 25 & $\operatorname{Rim}$ & 67.0 & 1290 & 185 & 300 & 4070 & 180 \\
\hline
\end{tabular}

sector is enriched in $\mathrm{Fe}$ but depleted in Ti. No distinct variation in $\mathrm{Mg}, \mathrm{K}$, and $\mathrm{Sr}$ was found between sectors. Bryan (1974) reported enrichment of both $\mathrm{Fe}$ and $\mathrm{Mg}$ in the calcic prism sectors.

\section{Tabular Crystals with Rounded and Embayed Cores}

Crystals 1, 7, 9, and 11 are characterized by rounded and embayed cores that generally have compositions between $\mathrm{An}_{82}$ and $\mathrm{An}_{80}$ (Figs. 14 and 15). The core of crystal 9 is bordered on one side by a calcic $\left(\mathrm{An}_{84}\right)$ patch and all of the cores are sharply bounded by more sodic $\left(\mathrm{An}_{75-70}\right)$ mantles that exhibit fine-scale oscillatory zoning, including a sodic $\left(A n_{70}\right)$ ribbon $(\sim 10 \mu \mathrm{m}$ in thickness) adjacent to the core. Mantles are surrounded by distinct narrow rims that are normally zoned from $\mathrm{An}_{65}$ to $\mathrm{An}_{61}$.

The rounded and embayed shape of the cores may possibly reflect a continuous crystal growth mechanism operative at low degrees of supercooling where growth rates are controlled by interface processes, as opposed to faceted crystals which are also produced at low degrees of supercooling but by a layer mechanism (Dowty, 1980). Plagioclase crystals produced in experiments at low degrees of supercooling, however, do not tend to be rounded (e.g., Lofgren, 1980). One might also argue that the embayments are a form of skeletal growth produced at high degrees of supercooling when growth rates are controlled either by volume diffusion in the liquid or removal of latent heat from the interface. Certainly, this is a viable mechanism for generating the compositional zoning pattern seen in crystal 11 (Fig. 15), where an embayed/skeletal calcic core $\left(\mathrm{An}_{80-82}\right)$ is surrounded by a more sodic mantle and rim. Sudden supercooling and skeletal growth may have been promoted by mixing with a lower temperature more sodic melt and/or by magma transport into a cooler environment, e.g., on or near the seafloor.

Alternatively, all or some of the embayed and rounded zones are the result of resorption, indicating disequilibrium between crystal and melt. Corrosion of crystal cores could have been caused by mixing of crystals and host melt with a hotter more primitive melt. Such an interpretation is supported by the calcic patch around the core of crystal 9 .

\section{DISCUSSION}

The composition of plagioclase feldspars crystallizing from a basaltic melt is controlled by melt composition, temperature, pressure, crystal growth rate, and interface kinetics (see Smith and Brown, 1988, for a recent review). Volatile content is an important compositional parameter, e.g., higher water contents promote crystallization of more calcic plagioclase (Kudo and Weill, 1970). Changes in melt composition may be brought on by normal liquid differentiation due to crystallization or by mixing of melts of different compositions. Variations in growth rate may lead to a departure from equilibrium partitioning between crystals and melt, e.g., greater incorporation of $\mathrm{Mg}$ and $\mathrm{Fe}$ into rapidly grown plagioclase (Lofgren et al., 1974). All of these parameters must be considered when interpreting compositional zoning in plagioclase.

\section{Origin of Patchy Zoning}

The origin of patchy zoning in plagioclase crystals has been explained by two different processes: (1) skeletal or dendritic crystal growth followed by infilling and growth of plagioclase of a different composition (Hibbard, 1981; Kuo and Kirkpatrick, 1982), and (2) resorption of plagioclase of one composition followed by overgrowth of plagioclase of another composition (Vance, 1965; Maaloe, 1976). Several pieces of evidence in Hole $648 \mathrm{~B}$ plagioclase crystals bear on this problem. The skeletal zones are always more calcic and more homogeneous than the enclosed patches. The sodic patches are strongly zoned to even more sodic compositions near melt inclusions. The patches are also enriched in $\mathrm{Mg}, \mathrm{K}, \mathrm{Ti}$, and $\mathrm{Fe}$ and have lower $\mathrm{Mg} /(\mathrm{Mg}+\mathrm{Fe})$ ratios compared to the skeletal zones. Patches generally have rectilinear outlines and are elongated 


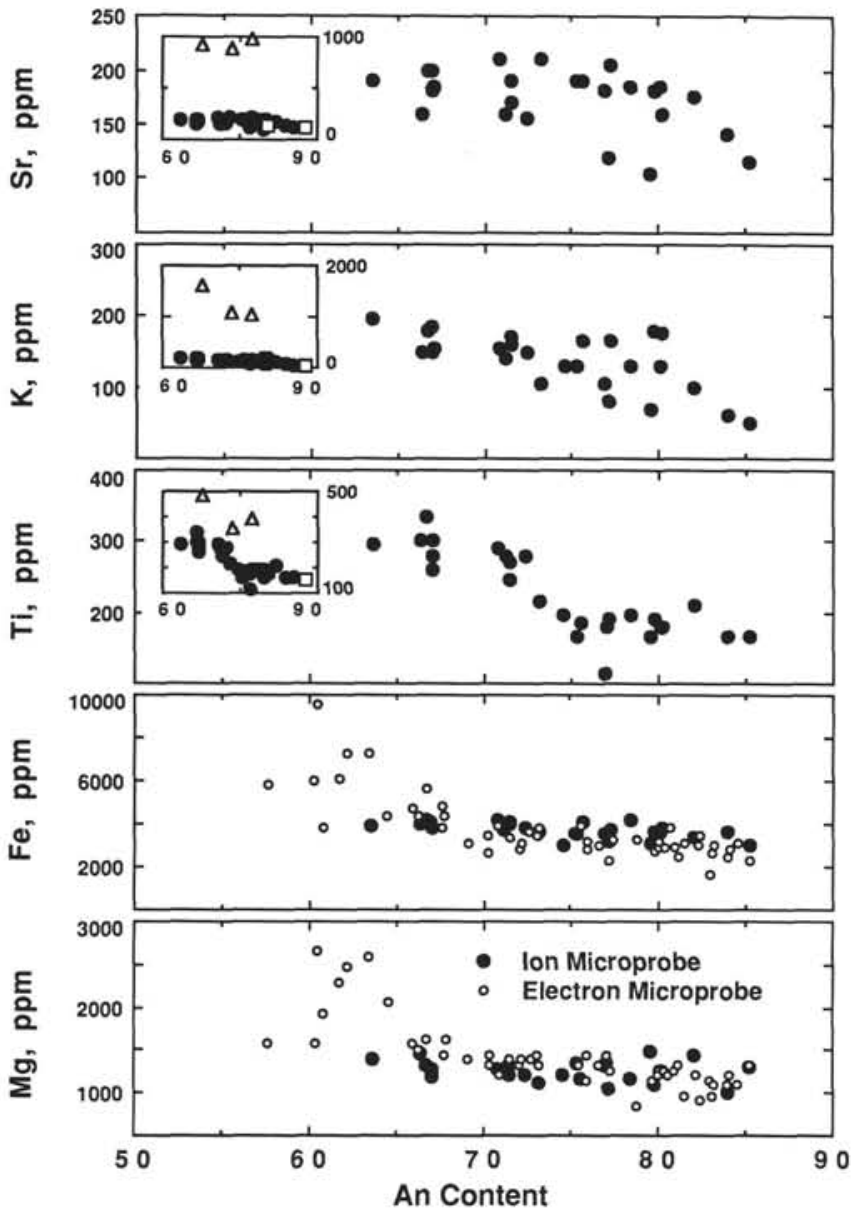

Figure 2. Minor and trace element concentrations of plagioclase phenocrysts in basalts from Hole 648B. Insets compare concentrations in Hole 648B plagioclases with plagioclase phenocrysts in tholeiitic (open squares) and alkalic basalts (open triangles) from the Southwest Indian Ridge (Meyer, unpubl. data).

Table 3. Representative electron microprobe analyses of olivine phenocrysts in Hole 648B lava.

\begin{tabular}{lrrr}
\hline & Core 1 & Rim 1 & Core 2 \\
$\mathrm{SiO}_{2}$ & 39.94 & 39.72 & 39.34 \\
$\mathrm{FeO}$ & 14.58 & 14.93 & 14.87 \\
$\mathrm{MnO}$ & 0.21 & 0.17 & 0.14 \\
$\mathrm{MgO}$ & 45.30 & 45.15 & 45.04 \\
$\mathrm{CaO}$ & 0.28 & 0.30 & 0.24 \\
$\mathrm{NiO}$ & 0.22 & 0.08 & 0.18 \\
& & & \\
Total & 100.53 & 100.35 & 99.81 \\
& & & \\
$\mathrm{Fo}$ & 84.7 & 84.3 & 84.3 \\
$\mathrm{Fa}$ & 15.3 & 15.7 & 15.7 \\
\hline
\end{tabular}

perpendicular to (010) as are the neighboring melt inclusions. These data, therefore, are most consistent with skeletal crystal growth and entrapment of melt, followed by crystallization and fractionation of trapped melt to form the patches.

\section{Crystal Growth Rates}

The various crystal shapes and zone morphologies suggest different crystal growth rates due to different cooling rates or
Table 4. Bulk compositions of Hole 648B lava and Makaopuhi lava lake.

\begin{tabular}{|c|c|c|c|}
\hline & $\begin{array}{c}\text { Hole } 648 B^{1} \\
\text { Glass }\end{array}$ & $\begin{array}{l}\text { Hole 648B } 1 \\
\text { Whole rock }\end{array}$ & $\begin{array}{c}\text { Makaopuhi }{ }^{2} \\
\text { lava lake }\end{array}$ \\
\hline $\mathrm{SiO}_{2}$ & 50.33 & 49.78 & 50.21 \\
\hline $\mathrm{TiO}_{2}$ & 1.77 & 1.68 & 2.63 \\
\hline $\mathrm{Al}_{2} \mathrm{O}_{3}$ & 15.76 & 16.15 & 13.36 \\
\hline $\mathrm{FeO}^{*}$ & 10.02 & 9.94 & 11.13 \\
\hline $\mathrm{MnO}$ & 0.20 & 0.17 & 0.17 \\
\hline $\mathrm{MgO}$ & 7.60 & 7.74 & 8.34 \\
\hline $\mathrm{CaO}$ & 11.11 & 11.42 & 10.81 \\
\hline $\mathrm{Na}_{2} \mathrm{O}$ & 3.00 & 2.84 & 2.34 \\
\hline $\mathrm{K}_{2} \mathrm{O}$ & 0.14 & 0.19 & 0.55 \\
\hline $\mathrm{P}_{2} \mathrm{O}_{5}$ & 0.16 & 0.17 & 0.27 \\
\hline Total & 100.09 & 100.08 & 99.81 \\
\hline LOI & & 0.23 & 0.11 \\
\hline $\mathrm{Ni}$ & & 108 & \\
\hline $\mathrm{Sr}$ & & 144 & \\
\hline $\mathrm{Zr}$ & & 128 & \\
\hline
\end{tabular}

1. Data from Detrick, Honnorez, Bryan, Juteau, et al. (1988).

2. Data from Kirkpatrick (1977).

different degrees of supercooling of the liquids in which the crystals grew. Lofgren $(1974,1980)$ showed experimentally that the shape of plagioclase changes progressively from tabular, to elongate skeletal, to dendritic, to spherulitic with increasing degree of supercooling from $40^{\circ} \mathrm{C}$ to $350^{\circ} \mathrm{C}$ below the liquidus or with increasing cooling rates from $2^{\circ} \mathrm{C} / \mathrm{hr}$ to $130^{\circ} \mathrm{C} / \mathrm{hr}$. Sector zoning in plagioclase has been experimentally produced in runs at low to moderate $\left(1^{\circ}-50^{\circ} \mathrm{C} / \mathrm{hr}\right)$ cooling rates (Lofgren, 1980). The importance of these studies to the present study is that they imply slow growth rates under near equilibrium conditions for the prismatic cores, moderate cooling and growth rates for the sector zoned crystals, and rapid growth rates for the needle-like rims.

Estimates of crystal growth rates can be made based on the empirical results of Kirkpatrick (1977) who studied Hawaiian lavas with compositions broadly similar to that of Hole 648B (Table 4). Kirkpatrick measured the number and size of plagioclase crystals in cores drilled into cooling lava lakes over a 3-yr period. He estimated that plagioclase growth rates ranged from 2 to $11 \times 10^{-10} \mathrm{~cm}^{-5}$, indicative of growth at small undercooling. Based on these estimates, the largest $(5 \mathrm{~mm})$ plagioclase phenocrysts in Hole 648B basalts grew in 15-80 $\mathrm{yr}$, implying very slow cooling of a magma body, located either in the lower crust or upper mantle where the temperature contrast between magma and wall rock is small or possibly in the upper crust if magmatic cooling due to hydrothermal convection is minimal (Marsh, 1989).

\section{Trace Element Partitioning}

Varied growth rates not only lead to a variety of crystal morphologies but also play an important role in controlling minor and trace element behavior. Stable growth leads to equilibrium partitioning of minor and trace elements between crystals and melt while unstable growth results in departures from equilibrium partitioning. In Hole 648B plagioclases, stable growth is represented by the tabular cores and inner rims. The inner rims exhibit a relatively narrow range in composition and appear to have been in equilibrium with surrounding melt (now glass). Outer rims, including dendritic overgrowths, on the other hand, 


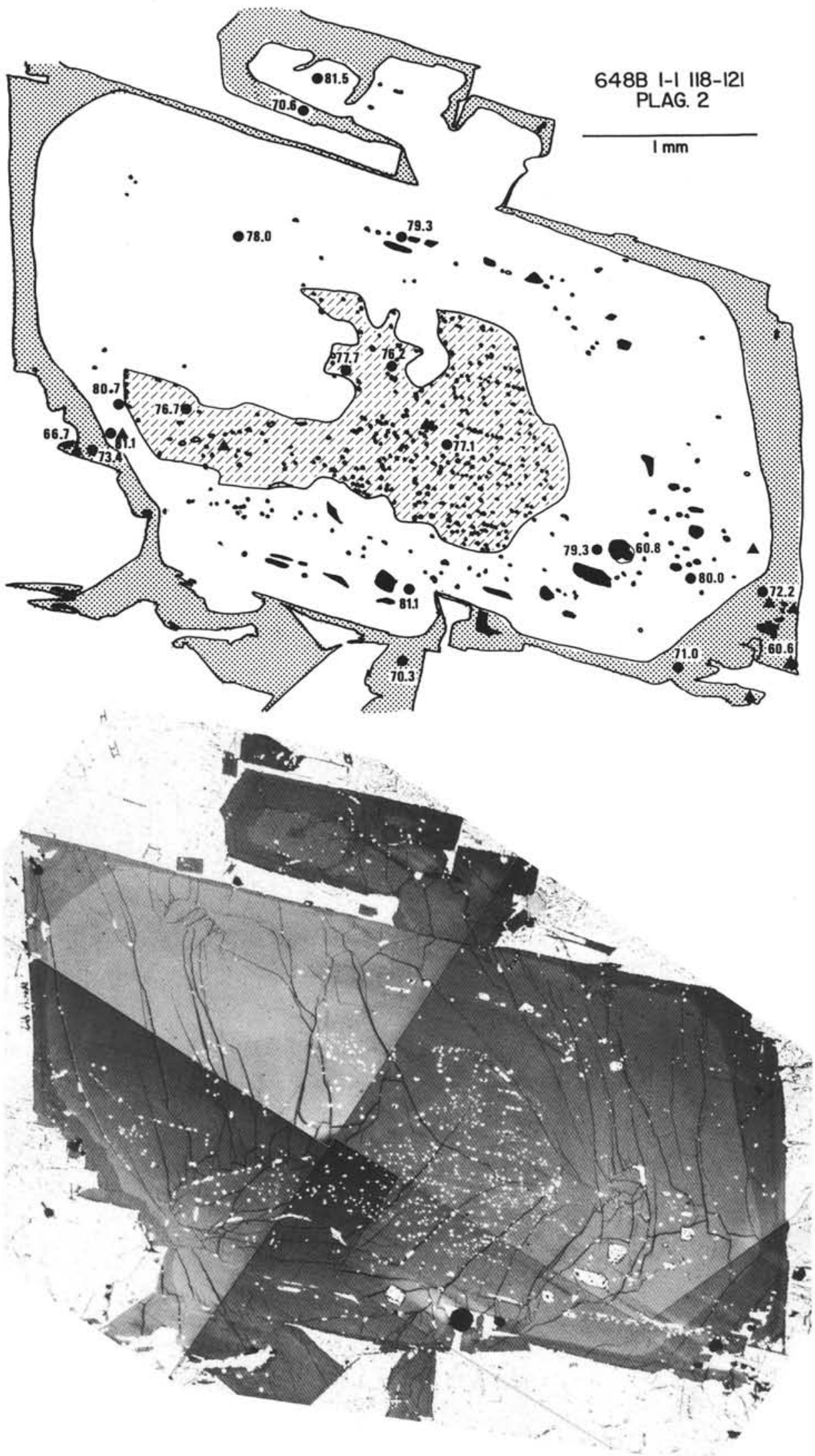

Figure 3. Major compositional zones in crystal 3 based on back-scattered electron images (BEI) (lower picture) and electron microprobe analyses (labeled points in upper diagram indicate anorthite content). Lighter grays in BEI indicate higher average atomic element compositions, corresponding to higher anorthite contents in plagioclase. Black areas in upper diagram depict melt inclusions. 


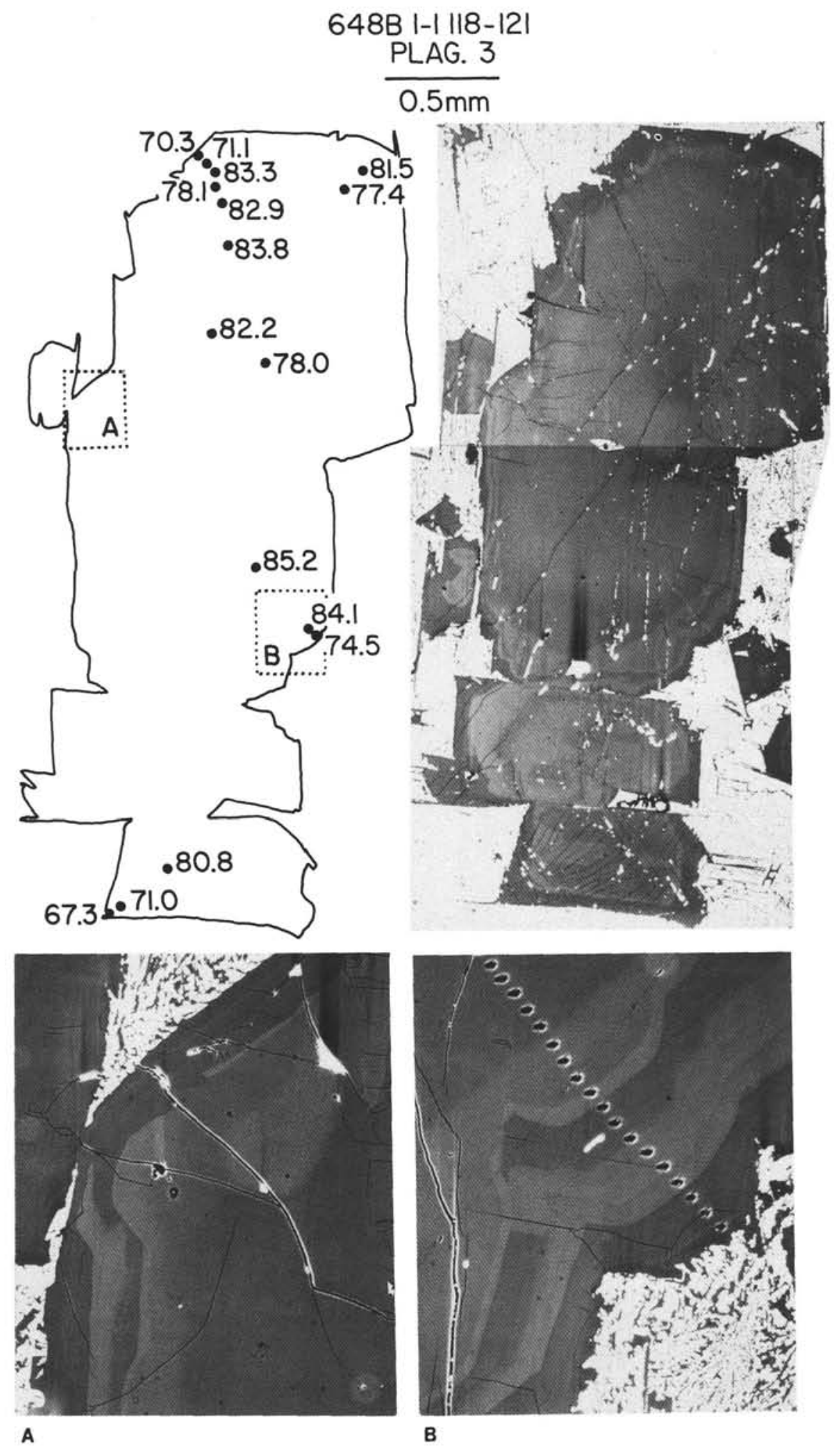

Figure 4. BEI and anorthite contents of crystal 4. A and $\mathbf{B}$ are enlargements of the complexly zoned mantle (locations of $\mathbf{A}$ and $\mathbf{B}$ are shown in the sketch in upper left). The location of the ion microprobe traverse in Figure 5 is shown by the line of analysis craters in $\mathbf{B}$. 


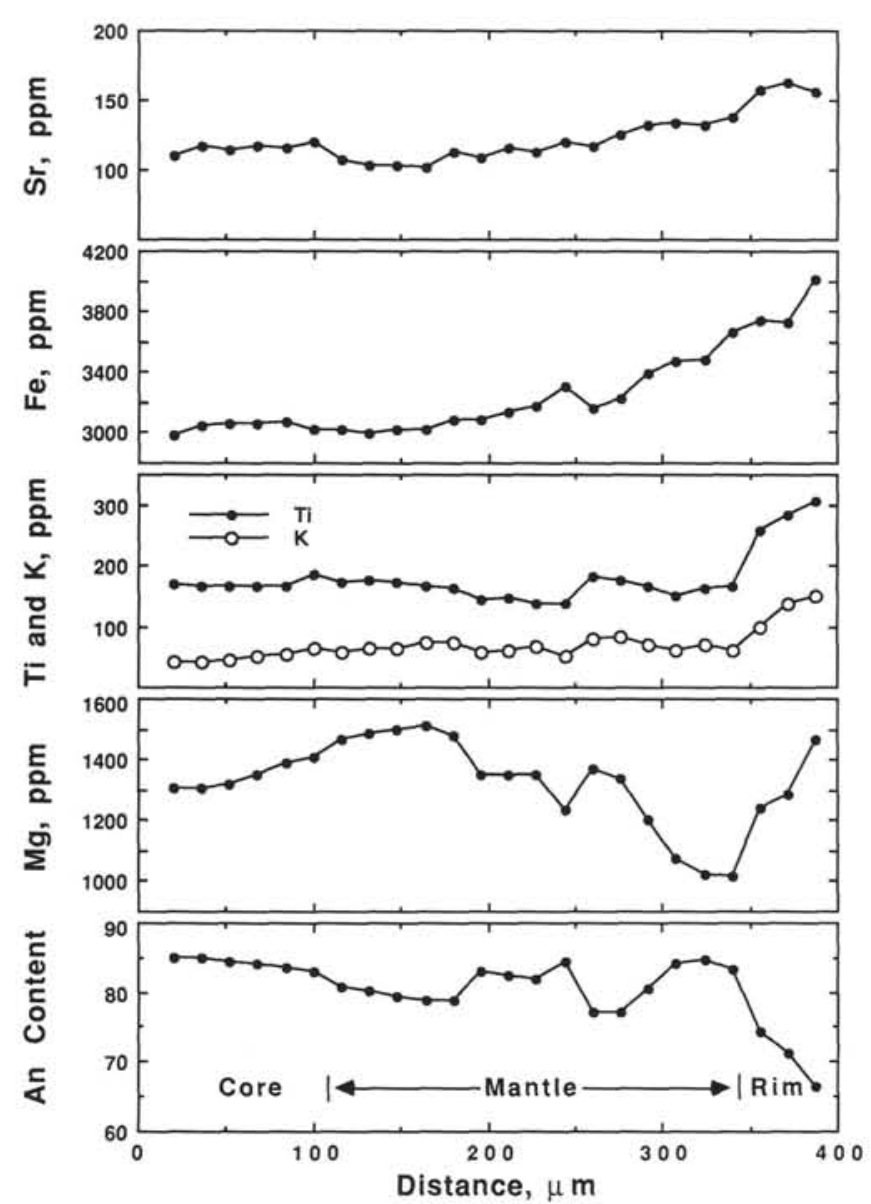

Figure 5. Core-to-rim zoning profile in Crystal 4. Location of traverse is shown in Figure 4. Note that $\mathrm{Fe}$ and $\mathrm{Sr}$ increase steadily from core to rim while $\mathrm{K}, \mathrm{Ti}$, and $\mathrm{Mg}$ show oscillations that are antithetic to the variations in An content.

exhibit tremendous compositional ranges that are related to rapid crystal growth during quenching of surrounding melt. The crystal/liquid distribution coefficient $\left(\mathrm{K}_{\mathrm{D}}=\left(\mathrm{X}_{\mathrm{Ca}} / \mathrm{X}_{\mathrm{Na}}\right)^{\text {)lag }} \times\left(\mathrm{X}_{\mathrm{Na}}\right)\right.$ $\left.\mathrm{X}_{\mathrm{Ca}}\right)^{\text {liq }}$ ) determined for the inner rim and 648B glass is 1.10 , which agrees well with the experimentally determined value (Grove and Bryan, 1983; Grove et al., this volume). Considering only the compositions of tabular cores and inner rims, $\mathrm{Mg}, \mathrm{K}, \mathrm{Ti}$, and $\mathrm{Fe}$ increase whereas $\mathrm{Mg} /(\mathrm{Mg}+\mathrm{Fe})$ decreases with decreasing anorthite content.

Using the average inner rim compositions and the composition of 648B glass (Detrick, Honnorez, Bryan, Juteau, et al., 1988), we derive the following partition coefficients: $\mathrm{Mg}=$ $0.03 ; \mathrm{K}=0.15 ; \mathrm{Ti}=0.028 ; \mathrm{Fe}=0.05 ; \mathrm{Sr}=1.32$. The values for $\mathrm{Mg}$ and $\mathrm{Fe}$ are close to those $(0.04$ and 0.058$)$ reported by Longhi et al. (1976) for terrestrial basalts. The value for $\mathrm{K}$ is the same as that reported by Philpotts and Schnetzler (1970) for a plagioclase/matrix pair. Our value for $\mathrm{Ti}$ is lower than most values reported for basalts, e.g., Smith and Brown (1988) quote values of 0.045 and 0.05 for plagioclase in alkali basalts. Our $\mathrm{Sr}$ value is slightly lower than that $(1.5)$ found by Sun et al. (1974) for oceanic basalts at temperatures near $1200^{\circ} \mathrm{C}$ but the same as the value found by Philpotts and Schnetzler (1970) for a basalt/matrix pair. In addition, the calculated $\mathrm{Fe}-\mathrm{Mg} \mathrm{K}$ $=1.68\left(\mathrm{~K}_{\mathrm{D}}=\left(\mathrm{X}_{\mathrm{Fe}} / \mathrm{X}_{\mathrm{Mg}}\right)^{\text {plag }} \times\left(\mathrm{X}_{\mathrm{Mg}} / \mathrm{X}_{\mathrm{Fe}}\right)^{\text {glass }}\right)$, which is nearly identical to the experimental value of 1.74 reported by Grove et al. (this volume).
Two types of disequilibrium partitioning are manifested in the Hole 648B plagioclases. The first is evident in the outer rims of crystals, particularly in the acicular, dendritic overgrowths on crystal rims which formed during quenching. These needles are progressively more sodic toward their tips and exhibit enrichments in $\mathrm{K}, \mathrm{Mg}$, and $\mathrm{Fe}$ that are much greater than expected from liquid evolution and equilibrium partition coefficients, i.e., the concentrations fall above the equilibrium trends defined by core and inner rim compositions. The enrichment in crystal rims of trace elements normally excluded from plagioclase $(\mathrm{Mg}, \mathrm{K}, \mathrm{Ti}, \mathrm{Fe})$ is probably the result of growth rates exceeding diffusion rates in the boundary layer. Crystallization anisotropy, i.e., variations in growth rate of different crystal faces, leads to additional compositional variation in crystal rims, e.g., $\mathrm{An}_{70-60}$ and 3800-6600 ppm Fe.

A second type of disequilibrium partitioning is recorded in skeletal zones, sector zones, and narrow mantles. In each case, calcic plagioclase $\left(\mathrm{An}_{81-78}\right)$ coexists with more sodic plagioclase $\left(A n_{75-70}\right)$. Zoning profiles through these zones (Figs. 5, 11, and 13) indicate that $\mathrm{Fe}$ and $\mathrm{Sr}$ are preferentially incorporated into the more calcic zones whereas $\mathrm{Mg}, \mathrm{K}$, and $\mathrm{Ti}$ are preferentially excluded. Variation diagrams with minor and trace elements plotted against anorthite content (Figs. 16 and 17) further show that $\mathrm{Fe}$ and $\mathrm{Sr}$ concentrations in the calcic zones lie above the equilibrium crystallization trend defined by core and inner rim compositions while $\mathrm{Mg}$ concentrations fall below, resulting in a dramatic lowering of the $\mathrm{Mg} /(\mathrm{Mg}+\mathrm{Fe})$ ratio in the skeletal and acicular calcic zones. In contrast, $\mathrm{K}$ and $\mathrm{Ti}$ concentrations in the calcic zones lie within analytical error of the equilibrium trends. We have no explanation for these departures from equilibrium partitioning but suggest that they reflect crystal-chemical effects associated with near simultaneous crystallization of calcic and sodic plagioclase.

\section{Pre-eruptive History of Hole 648B Plagioclase Crystals and Petrogenetic Implications}

Keeping in mind the possible effect of crystallization kinetics on trace element partitioning, we can estimate the composition of parental liquid(s) from the composition of phenocryst cores. Presumably, these zones represent stable crystal growth under near-equilibrium conditions. Using the core composition of crystal 4 (Table 2) and the partition coefficients derived above, the coexisting melt had the following composition: $\mathrm{Mg} /(\mathrm{Mg}+\mathrm{Fe})=0.626, \mathrm{Ca} /(\mathrm{Ca}+\mathrm{Na})=0.816, \mathrm{~K}_{2} \mathrm{O}=$ $0.04 \mathrm{wt} \%, \mathrm{TiO}_{2}=0.98 \mathrm{wt} \%$, and $\mathrm{Sr}=87 \mathrm{ppm}$. The calculated $\mathrm{Ca} /(\mathrm{Ca}+\mathrm{Na})$ ratio is based on a Ca-Na $\mathrm{K}_{\mathrm{D}}$ of 1.3 which was derived for plagioclase/melt at $1200^{\circ} \mathrm{C}$ from a $\mathrm{K}_{\mathrm{D}}$ vs. temperature plot of experimental data (Fisk, 1978; Grove and Bryan, 1983; Grove et al., this volume). There is considerable scatter in this diagram, but a clear indication of higher $\mathrm{K}_{\mathrm{D}}$ 's at higher temperatures. For comparison, a $\mathrm{K}_{\mathrm{D}}=1.1$ gives a calculated $\mathrm{Ca} /(\mathrm{Ca}+\mathrm{Na})$ ratio of 0.84 for liquid in equilibrium with the core of crystal $4\left(\mathrm{An}_{85.2}\right)$.

In Table 5, the calculated liquid composition for crystal 4 is compared to the compositions of primitive basalts from the Kane Fracture Zone (KFZ) and to basalts from other segments of the MAR. The calculated melt composition is similar to two KFZ basalts except for its lower $\mathrm{K}_{2} \mathrm{O}$ and significantly higher $\mathrm{Ca} /(\mathrm{Ca}+\mathrm{Na})$ ratio. Basalts from Iceland and the Jan Mayen Ridge north of Iceland (Sigurdsson, 1981) have the most similar compositions. The high $\mathrm{Ca} /(\mathrm{Ca}+\mathrm{Na})$ ratio for these basalts is probably related to higher degrees of mantle melting associated with the Iceland mantle plume (see Bryan and Dick, 1982; Schilling et al., 1983; and Klein and Langmuir, 1987, for the relationship between degree of melting, mantle plumes, and $\mathrm{Ca} /(\mathrm{Ca}+\mathrm{Na})$ ratios $)$. High 

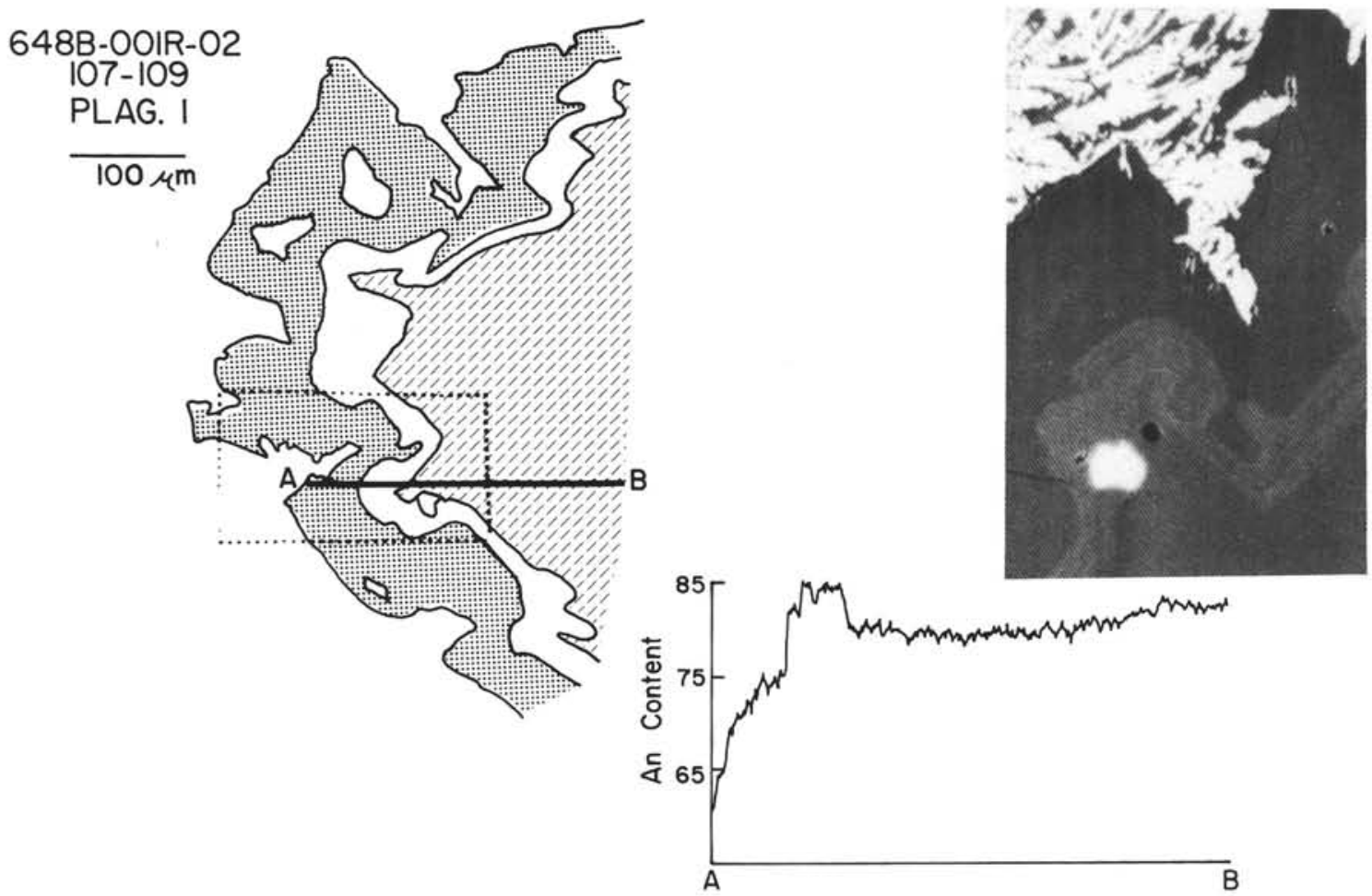

Figure 6. Sketch and BEI of the outer margin of crystal 8 . The zoning profile shows slight normal zoning in the core, a $100-\mu \mathrm{m}$-wide calcic mantle, and strong normal zoning in the rim. Shading patterns indicate the major compositional zones, the darker the pattern the more sodic the average composition.

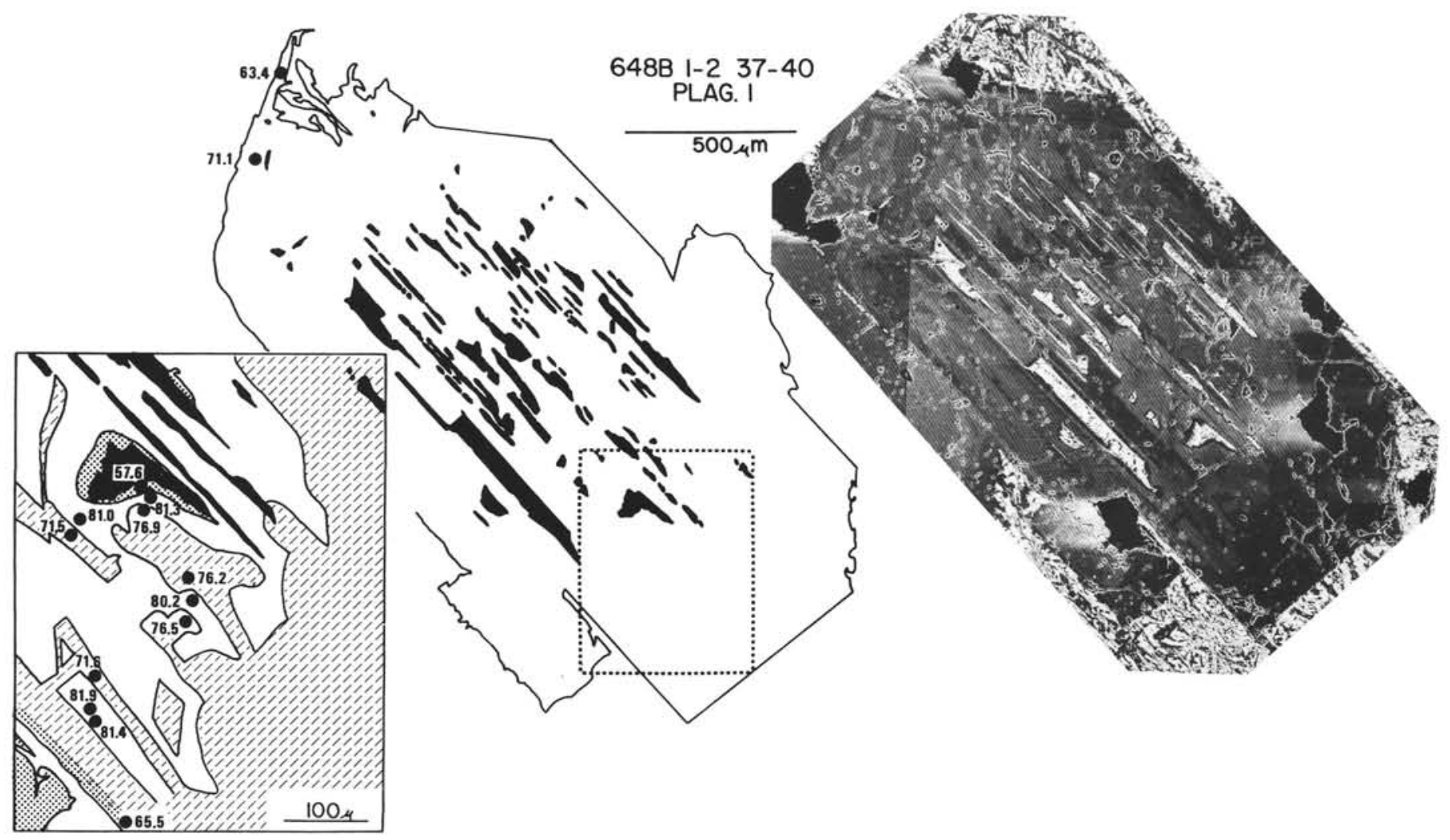

Figure 7. Sketch and BEI of crystal 5 showing skeletal core and patchy zoning. Shading patterns in left inset indicate major compositional zones, the darker the pattern the more sodic the average composition. Numbers indicate anorthite contents. Black areas depict trapped melt inclusions. Note that the core is relatively homogeneous $\left(\mathrm{An}_{81}\right)$ while enclosed patches show strong zonation $\left(\mathrm{An}_{77-71}\right)$. 

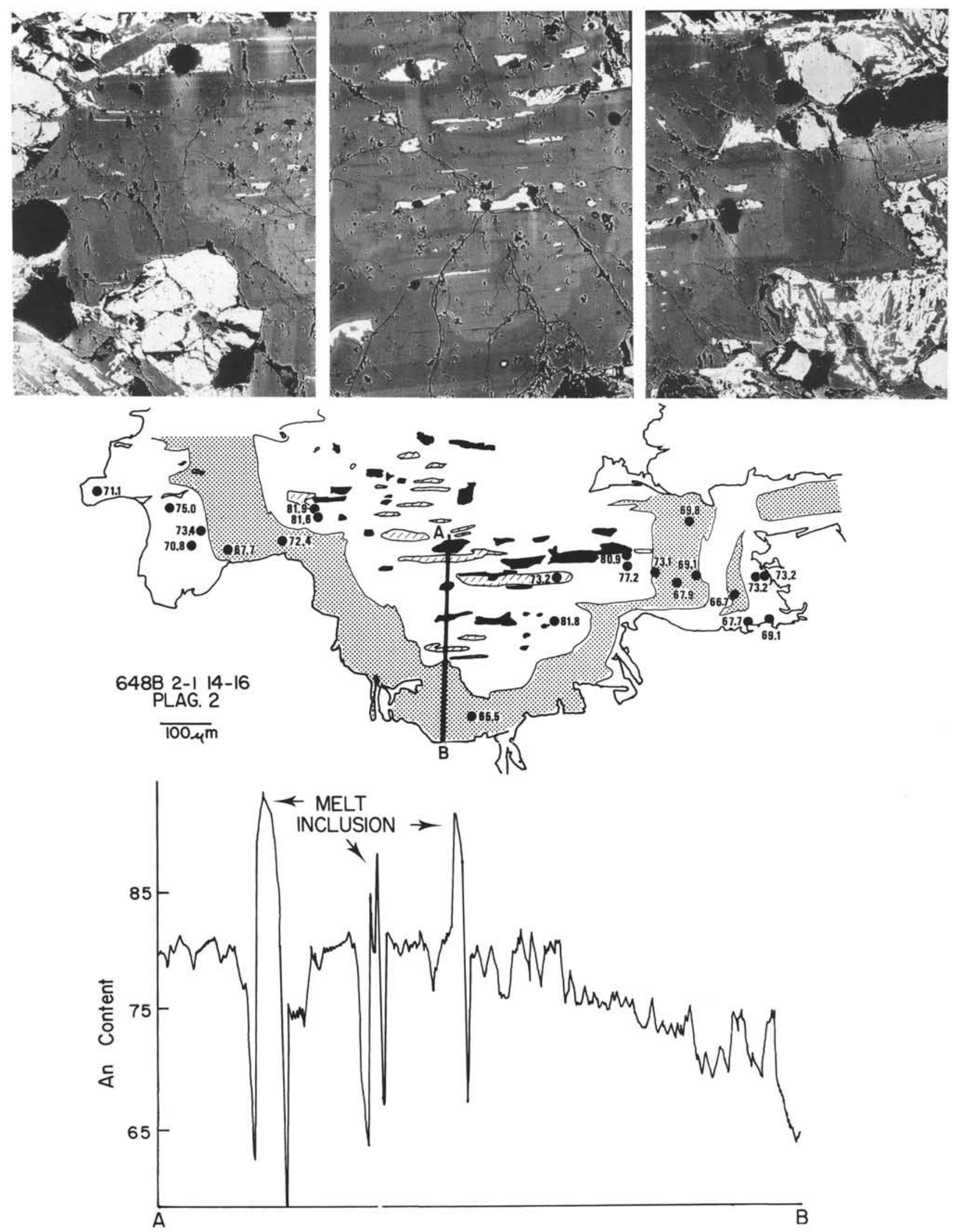

Figure 8. Sketch and BEI of crystal 19 showing skeletal core, patchy zoning, and a core-to-rim traverse. Shading patterns indicate major compositional breaks, the darker the pattern the more sodic the average composition. Black areas depict melt inclusions. Note the baseline

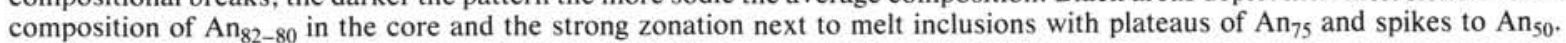




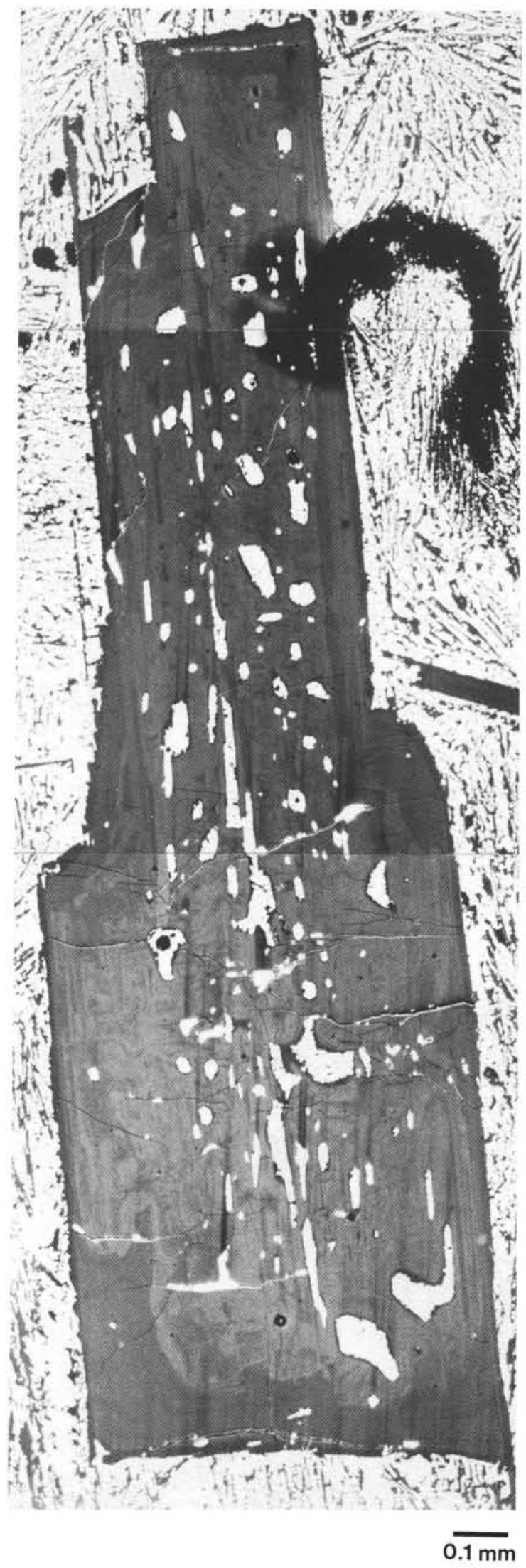

Figure 9. BEI of crystal 22 showing patchy zoning around melt inclusions. Core is marked by curvilinear calcic $\left(\mathrm{An}_{81.5}\right)$ patches (light gray) surrounding sodic $\left(\mathrm{An}_{75.5}\right)$ patches (darker gray) and melt inclusions.
$\mathrm{Ca} /(\mathrm{Ca}+\mathrm{Na})$ ratios in the vicinity of Hole $648 \mathrm{~B}$ may imply high degrees of melting, but there is no other evidence of large scale melting, e.g., increased crustal thickness, in this region. Alternatively, the calcic compositions may be related to a refractory mantle domain in a locally heterogeneous mantle (Natland, 1989).

Hole 648B plagioclase crystals clearly record the existence of a primitive liquid in the Serocki magmatic system as well as a mixing event between primitive and evolved liquids. We cannot tell how these different liquids were spatially related in the axial magmatic system, i.e., within a single convecting magma chamber or in reservoirs at different depths. Considering the postulated turbulent nature of a small ( $2 \mathrm{~km}$ wide) basaltic magma chamber beneath the seafloor (e.g., Huppert and Sparks, 1980) and the likelihood of homogenization, we speculate that the melts were stored in separate reservoirs and that a small volume of primitive melt was injected, either laterally or from below, into the Serocki magmatic system just prior to the eruption that formed the small volcanic edifice. This configuration is supported by the relative proportions of plagioclase compositions and the sequence of plagioclase crystallization. Specifically, a major crystallization event from a moderately evolved melt is implied from homogeneous cores and mantles, $0.2-0.4 \mathrm{~cm}$ in diameter, with compositions in the range from $A n_{81}$ to $A n_{78}$. Plagioclase in this compositional range is by far the most important volumetrically. That this event took place before injection of primitive melt is indicated by the calcic, low $\mathrm{K}$, and low Ti mantles around tabular cores. The magma composition inferred from the $\mathrm{An}_{81-78}$ cores is as follows: $\mathrm{Ca} /(\mathrm{Ca}+\mathrm{Na})=0.74-0.79, \mathrm{Mg} /(\mathrm{Mg}+\mathrm{Fe})=$ $0.52-0.56, \mathrm{~K}_{2} \mathrm{O}=0.08-0.11 \mathrm{wt} \%, \mathrm{TiO}_{2}=1.0-1.3 \mathrm{wt} \%$, and $\mathrm{Sr}=130-140 \mathrm{ppm}$ (Table 5).

Varied zoning morphologies in Hole 648B plagioclases imply varied pre-eruptive histories of individual crystals. Four main zoning patterns need to be explained: (1) tabular $\left(A n_{84}\right)$ cores mantled by more sodic zones $\left(A n_{80}\right.$ and $\left.A n_{75}\right),(2)$ tabular $\left(A n_{80}\right)$ cores mantled by narrow $\left(\mathrm{An}_{84}\right.$ and $\left.A n_{75}\right)$ zones, (3) skeletal cores $\left(A n_{80-78}\right)$ enclosing sodic $\left(A n_{75}\right)$ patches, and (4) rounded cores $\left(A n_{75}\right)$ surrounded by skeletal $\left(A n_{80-78}\right)$ mantles. These diverse crystal types could have been produced in a magmatic system with three interconnected reservoirs or compartments that contained melts $(1,2,3)$ at different stages of evolution and in equilibrium with three different plagioclase compositions $\left(\mathrm{An}_{84}, \mathrm{An}_{80}\right.$, and $\left.\mathrm{An}_{75}\right)$. The first zoning pattern is then explained by successive crystallization as melt moved from compartment 1 to 2 to 3 . The second zoning configuration can be attributed to initial crystallization from melt 2 followed by entrainment in and crystallization from an inflowing pulse of melt 1 and then by migration of the crystal/ melt mixture into melt 3 . The third and fourth types of zoning can be attributed to introduction of melt 2 into melt 3 , causing resorption of crystals $\left(A n_{75}\right)$ in melt 3 and skeletal crystallization $\left(\mathrm{An}_{80}\right)$ from melt 2.

While there is good evidence for mixing of different melts, there is no evidence of varied parental melt compositions. Alkali basalt melts, for example, would crystallize plagioclase with significantly higher $\mathrm{K}, \mathrm{Ti}$, and $\mathrm{Sr}$ (Fig. 2). As noted above, the variations in trace element contents in Hole 648B plagioclase crystals can be attributed to different degrees of magma evolution or to crystallization kinetics.

The diverse morphologies and compositional variations exhibited by plagioclase phenocrysts in Hole 648B basalts are also characteristic of basalts drilled at Sites 395 (Natland, 1979a; Dungan et al., 1978; Kuo and Kirkpatrick, 1982) and 396 (Flower et al., 1978; Kirkpatrick, 1978). Sites 395 and 396 lie on a single seafloor spreading flow-line away from Hole $648 \mathrm{~B}$ on the axis of the MAR. Site 395 is located in 6-7 m.y. 

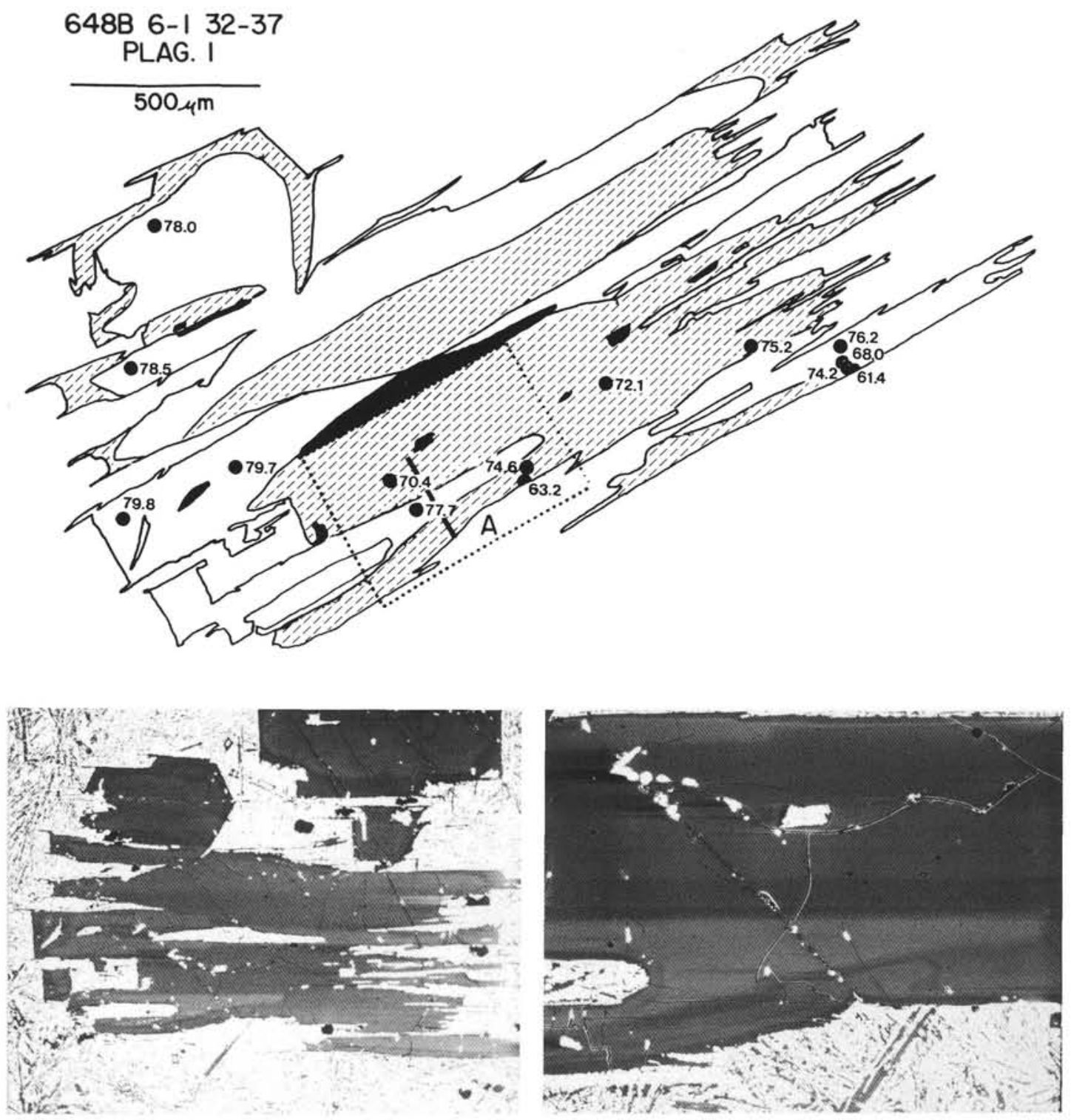

Figure 10. Sketch and BEI of crystal 20 showing skeletal outline and patchy zoning. Unshaded area in the sketch shows more calcic part of the crystal and the ruled pattern shows sodic areas. Trapped melt inclusions and groundmass are indicated by the black patches. Numbers give anorthite contents determined by electron microprobe. The bar passing through the calcic needle in the lower left part of the crystal shows the location of an ion microprobe traverse (Fig. 11).

old crust to the west of the MAR and Site 396 is located in 9-10 m.y. old crust to the east of the MAR. Thus, this segment of the MAR has been characterized by mixing of primitive and evolved melts for at least the last $10 \mathrm{~m}$.y. Mixing is probably the result of an intermittent magma supply. At Site 395, using magnetic and geochemical data, Johnson (1979) and Natland $(1979 \mathrm{~b})$ inferred that periods of volcanic activity were short $\left(\leq 10^{2} \mathrm{yr}\right)$ and episodic with long periods $\left(10^{3}-10^{4}\right.$ years $)$ of quiescence between episodes.

Mixed assemblages of plagioclase crystals have also been observed in other areas, e.g., the FAMOUS region (Hekinian et al., 1976; Bryan, 1979), Iceland (Meyer et al., 1985), and Hole 504B on the Costa Rica Rift (Natland et al., 1988), suggesting that such assemblages and implied magma mixing are widespread phenomena at slow to intermediate spreading mid-ocean ridges.

\section{ACKNOWLEDGMENTS}

We thank Nobu Shimizu for assistance with ion microprobe analyses and discussions on crystallization kinetics, K. D. Burrhus for technical assistance with the ion microprobe, S. Recca for technical assistance with the electron microprobe, and Margaret Sulanowska for expert assistance with the graphics. The paper benefited significantly from a review by Jim Natland. This work was supported by a grant from USSAC through the Texas A\&M Research Foundation to P. Meyer.

\section{REFERENCES}

Albee, A. L., and Ray, L., 1970. Correction factors for electron microprobe analysis of silicates, oxides, carbonates, phosphates and sulfates. Anal. Chem., 42:1408-1414.

Bence, A. E., and Albee, A. L., 1968. Empirical correction factors for the electron microanalysis of silicates and oxides. J. Geol., 76:382-403. 
Bender, J. F., Hodges, F. N., and Bence, A. E., 1978. Petrogenesis of basalts from the project FAMOUS area: Experimental study from 0 to 15 kbars. Earth Planet. Sci. Lett., 41:277-302.

Bryan, W. B., 1974. Fe-Mg relationships in sector-zoned submarine basalt plagioclase. Earth Planet. Sci. Lett., 24:1 57-165.

1979. Regional variation and petrogenesis of basaltic glasses from the FAMOUS Area, Mid-Atlantic Ridge. J. Petrol., 20:293-325.

Bryan, W. B., Thompson, G., and Ludden, J. N., 1981. Compositional variation in normal MORB from $22^{\circ}-25^{\circ} \mathrm{N}$ : Mid-Atlantic Ridge and Kane Fracture Zone. J. Geophys. Res., $86: 11,815-11,836$.

Bryan, W. B., and Dick, H.J.B., 1982. Contrasted abyssal basaltic liquidus trends: Evidence for mantle major element heterogeneity. Earth Planet. Sci. Lett., 58:15-26.

Bryan, W. B., and Moore, J. G., 1977. Compositional variations of young basalts in the Mid-Atlantic Ridge rift valley near latitude $36^{\circ} 49^{\prime}$ N. Geol. Soc. Am. Bull., 88:556-570.

Detrick, R., Honnorez, J., Bryan, W. B., Juteau, T., et al., 1988. Proc. ODP, Init. Repts., 106/109: College Station, TX (Ocean Drilling Program).

Dowty, Eric, 1980. Crystal growth and nucleation theory and the numerical simulation of igneous crystallization In Hargraves, R. B., (Ed.), Physics of Magmatic Processes. Princeton (Princeton Univ. Press), 419-485.

Dungan, M. A., Long, P. E., and Rhodes, J. M., 1978. The petrology, mineral chemistry, and one-atmosphere phase relations of basalts from Site 395. In Melson, W. G., Rabinowitz, P. D., et al., Init. Repts. DSDP, 45: Washington (U.S. Govt. Printing Office), 461-477.

Fisk, M. R., 1978. Melting relations and mineral chemistry of Iceland and Reykjanes Ridge basalts [Ph.D. dissert.]. Univ. of Rhode Island, Kingston.

Flower, M.F.J., Ohnmacht, W., Schmincke, H.-U., Gibson, I. L., Robinson, P. T., and Parker, R., 1978. Petrology and geochemistry of basalts from Hole 396B, Leg 46. In Dmitriev, L., Heirtzler, J., et al., Init. Repts. DSDP, 46: Washington, (U.S. Govt. Printing Office), 179-213.

Grove, T. L., and Bryan, W. B., 1983. Fractionation of pyroxenephyric MORB at low pressure: An experimental study. Contrib. Mineral. Petrol., 84:293-309.

Grove, T. L., Baker, M. B., and Kinzler, R. J., 1984. Coupled $\mathrm{CaAl}-\mathrm{NaSi}$ diffusion in plagioclase feldspar: Experiments and applications to cooling rate speedometry. Geochim. Cosmochim. Acta, 48:2113-2121.

Hekinian, R., Moore, J. G., and Bryan, W. B., 1976. Volcanic rocks and processes of the Mid-Atlantic Ridge rift valley near $36^{\circ} 49^{\prime} \mathrm{N}$. Contrib. Mineral. Petrol., 58:83-110.

Hibbard, M. J., 1981. The magma mixing origin of mantled feldspars. Contrib. Mineral. Petrol., 76:158-170.

Huppert, H. E., and Sparks, R.S.J., 1980. The fluid dynamics of a basaltic magma chamber replenished by influx of hot, dense ultrabasic magma. Contrib. Mineral. Petrol., 75:279-289.

Johnson, H. P., 1979. Paleomagnetism of igneous rock samplesDSDP Leg 45. In Melson, W. G., Rabinowitz, P. D., et al., Init. Repts. DSDP, 45: Washington (U.S. Govt. Printing Office), 387-395.

Kirkpatrick, R. J., 1977. Nucleation and growth of plagioclase, Makaopuhi and Alae lava lakes, Kilauea Volcano, Hawaii. Geol. Soc. Am. Bull., 88:78-84.

1978. Petrology of basalts: Hole 396B, DSDP Leg 46. In Dmitriev, L., Heirtzler, J., et al., Init. Repts. DSDP, 46: Washington (U.S. Govt. Printing Office), 165-178.

Klein, E. M., and Langmuir, C. H., 1987. Global correlations of ocean ridge basalt chemistry with axial depth and crustal thickness. J. Geophys. Res., 92:8089-8115.

Kudo, A. M., and Weill, D. F., 1970. An igneous thermometer. Contrib. Mineral. Petrol., 25:201-216.

Kuo, L.-C. and Kirkpatrick, R. J., 1982. Pre-eruptive history of phyric basalts from DSDP Legs 45 and 46: Evidence from morphology and zoning patterns in plagioclase. Contrib. Mineral. Petrol., 79:13-27.
Lofgren, G., 1974. An experimental study of plagioclase crystal morphology: isothermal crystallization. Am. J. Sci., 274:243-273. 1980. Experimental studies on the dynamic crystallization of silicate melts. In Hargraves, R. B., (Ed.), Physics of Magmatic Processes. Princeton (Princeton Univ. Press), 487-551.

Lofgren, G., Donaldson, C. H., Williams, R. J., Mullins, O., and Usselman, T. M., 1974. Experimentally reproduced textures and mineral chemistry of Apollo 15 quartz-normative basalts. Proc. 5th Lunar Sci. Conf., 549-567.

Longhi, J., Walker, D., and Hays, J. F., 1976. Fe and $\mathrm{Mg}$ in plagioclase. Proc. Lunar Sci. Conf. 7th, 1281-1300.

Maaloe, S., 1976. The zoned plagioclase of the Skaergaard intrusion, East Greenland. J. Petrol., 17:398-419.

Marsh, B. D., 1989. Magma chambers. Ann. Rev. Earth Planet. Sci. Lett., 17:439-74.

Meyer, C., Jr., Anderson, D. H., and Bradley, J. G., 1974. Ion microprobe mass-analysis of plagioclase from "non-mare" lunar samples. GCA Suppl,. 5:685-706.

Meyer, P. S., Sigurdsson, H. and Schilling, J.-G., 1985. Petrological and geochemical variations along Iceland's neovolcanic zones. $J$. Geophys. Res., 90:10,043-10,072.

Muir, I. D., and Tilley, C. E., 1964. Basalts from the northern part of the rift zone of the Mid-Atlantic Ridge. J. Petrol., 5:409-434.

Natland, J. H., 1979a. Crystal morphologies in basalts from DSDP Site $395,23^{\circ} \mathrm{N}, 46^{\circ} \mathrm{W}$, mid-Atlantic Ridge. In Melson, W. G. Rabinowitz, P. D., et al., Init. Repts. DSDP, 45: Washington (U.S. Govt. Printing Office), 423-445.

1979b. Comparison of chemical and magnetic stratigraphy of basement rocks at DSDP Sites 332 and 395. In Melson, W. G., Rabinowitz, P. D., et al., Init. Repts. DSDP, 45: Washington (U.S. Govt. Printing Office), 657-677.

1989. Partial melting of a lithologically heterogeneous mantle: inferences from crystallization histories of magnesian abyssal tholeiites from the Siqueiros Fracture Zone. In Saunders, A. D., and Norry, M. J. (Eds), Magmatism in the Ocean Basins. Geol. Soc. Spec. Publ., 42:41-70.

Natland, J. H., Adamson, A. C., Laverne, C., Melson, W. G., and O'Hearn, T. O., 1983. A compositionally nearly steady-state magma chamber at the Costa Rica Rift: evidence from basalt glass and mineral data, Deep Sea Drilling Project Sites 501, 504, and 505. In Cann, J. R., Langseth, M. G., Honnorez, J., von Herzen, R. P., White, S. M., et al., Init. Repts. DSDP, 69: Washington (U.S. Govt. Printing Office), 811-858.

Philpotts, J. A., and Schnetzler, C. C., 1970. Phenocrysts for K, Rb, $\mathrm{Sr}$, and $\mathrm{Ba}$, with applications to anorthosite and basalt genesis. Geochim. Cosmochim. Acta, 34:307-322.

Ray, G. L., 1980. An ion microprobe study of trace element partitioning between clinopyroxene and liquid in the diopside $\left(\mathrm{CaMgSi}_{2} \mathrm{O}_{5}\right)$-albite $\left(\mathrm{NaAlSi}_{3} \mathrm{O}_{8}\right)$-anorthite $\left(\mathrm{CaAl}_{2} \mathrm{Si}_{2} \mathrm{O}_{8}\right)$ system. [PhD dissert.]. Mass. Inst. Technol., Cambridge.

Schilling, J.-G., Zajac, M., Evans, R., Johnson, T., White, W., Devine, J. D., and Kingsley, R., 1983. Petrologic and geochemical variations along the Mid-Atlantic Ridge from $29^{\circ} \mathrm{N}$ to $73^{\circ} \mathrm{N}$. $\mathrm{Am} \mathrm{J}$. Sci., 283:510-586.

Shibata, T., DeLong, S. E., and Walker, D., 1979. Abyssal tholeiites from the Oceanographer Fracture Zone I. Petrology and fractionation. Contrib. Mineral Petrol., 70:89-102.

Shimizu, N., 1978. Analysis of the zoned plagioclase of different magmatic environments: A preliminary ion-microprobe study. Earth Planet. Sci. Lett., 39:398-406.

Shimizu, N., and Hart, S. R., 1982. Applications of the ion microprobe to geochemistry and cosmochemistry. Ann. Rev. Earth Planet. Sci., 10:483-526.

Shimizu, N., and le Roex, A. P., 1986. The chemical zoning of augite phenocrysts in alkaline basalts from Gough Island, South Atlantic. J. Volcanol. Geotherm. Res., 29:159-188.

Sigurdsson, Haraldur, 1981. First-order major element variation in basalt glasses from the Mid-Atlantic Ridge: $29^{\circ} \mathrm{N}$ to $73^{\circ} \mathrm{N}$. J. Geophys. Res., 86:9483-9502.

Smith, J. V., and Brown, W. L., 1988. Feldspar Minerals. Vol. 1. Crystal structures, Physical, Chemical, and Micro textural Properties. Berlin (Springer-Verlag), 838 p. 
Sun, C-O., Williams, R. J., and Sun, S. S., 1974. Distribution coefficients of Eu and $\mathrm{Sr}$ for plagioclase-liquid and clinopyroxene-liquid equilibria in oceanic ridge basalt: An experimental study. Geochim. Cosmochim. Acta, 38:1415-1433.

Vance, J. A., 1965. Zoning in igneous plagioclase: patchy zoning. $J$. Geol., 73:636-51.

Date of initial receipt: 12 October 1988

Date of acceptance: 21 April 1989

Ms 106/109B-135

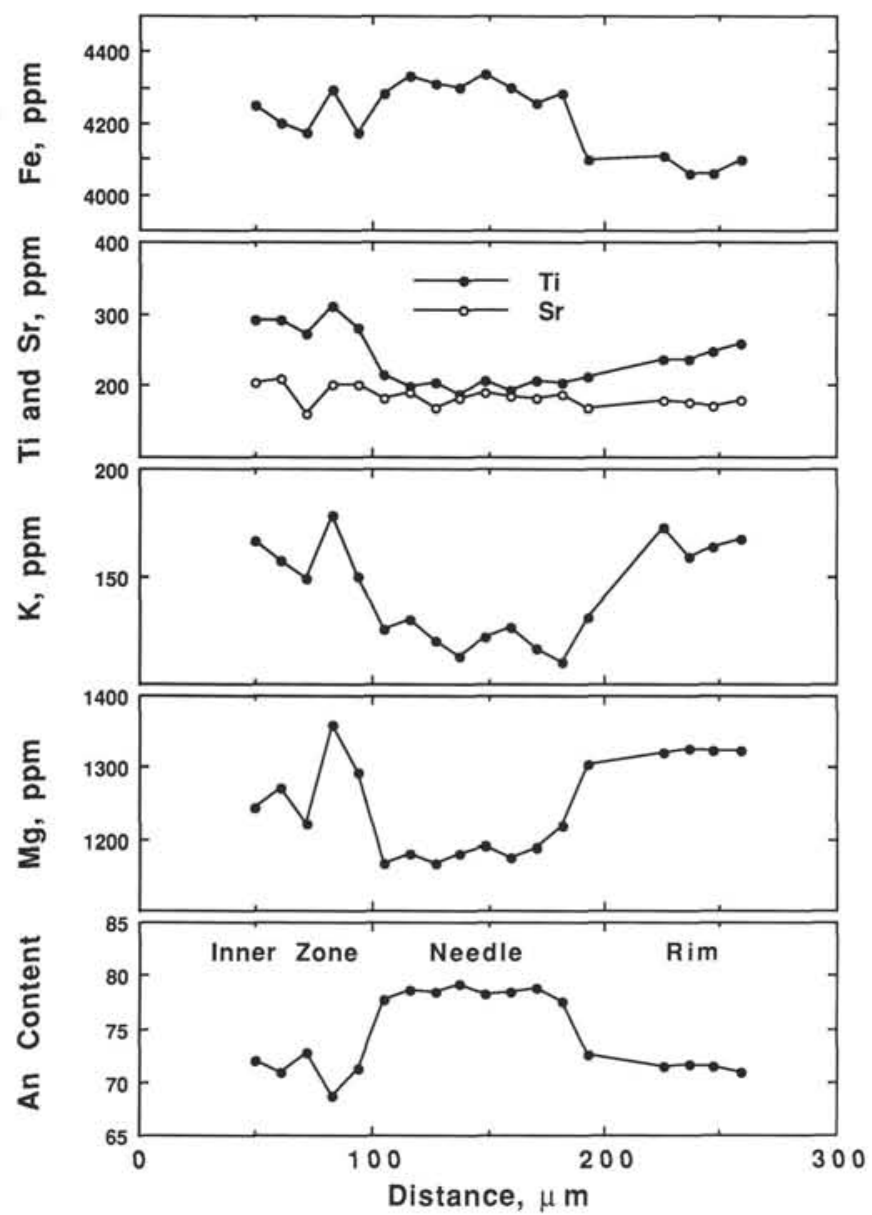

Figure 11. Zoning profile across a calcic needle in crystal 20 (Fig. 10). $\mathrm{Fe}$ varies in the same way as anorthite content while $\mathrm{Ti}, \mathrm{K}$, and $\mathrm{Mg}$ vary antithetically.
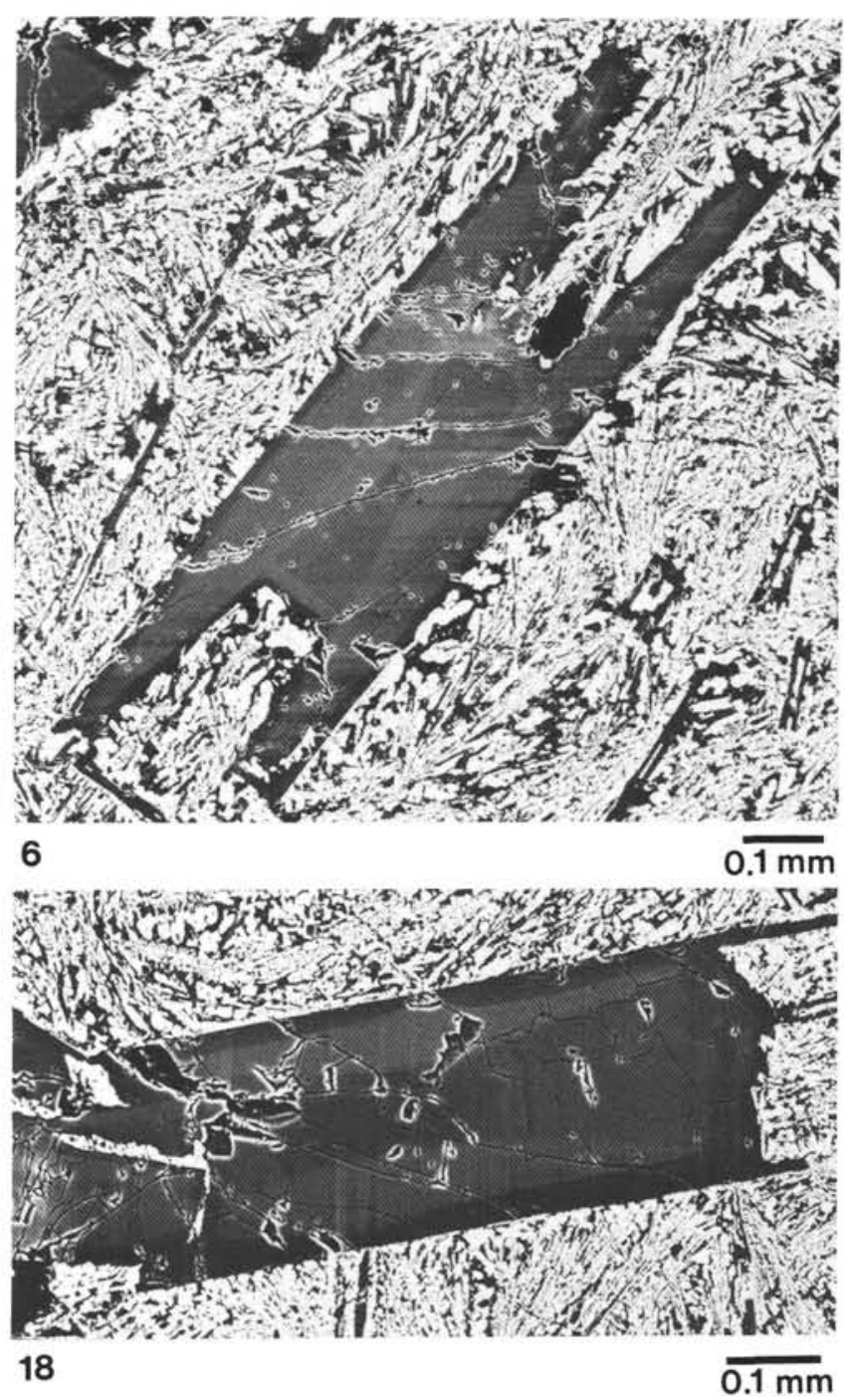

CRYSTAL 18

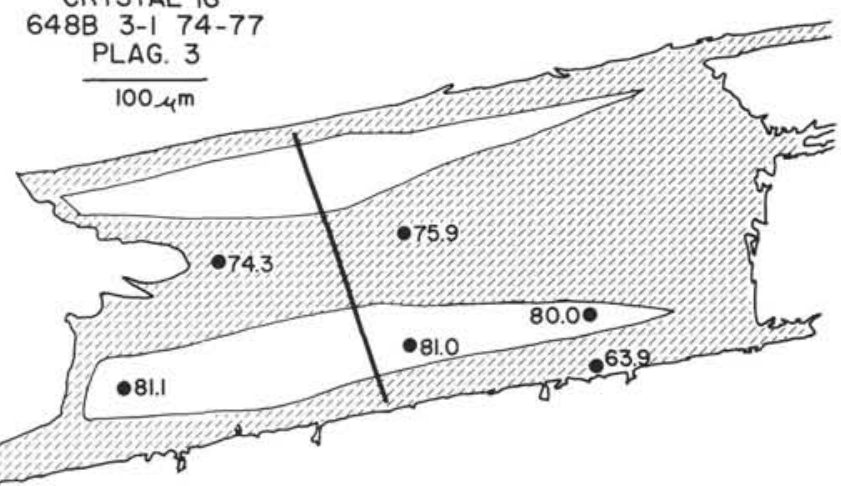

Figure 12. Sketch and BEI of sector-zoned plagioclase crystals. Unshaded areas in sketch indicate calcic $(010)$ sectors and shaded area indicates sodic (001) sectors and rims. Numbers refer to anorthite content determined by electron microprobe. Line through crystal shows the location of an ion microprobe traverse (Fig. 13). 


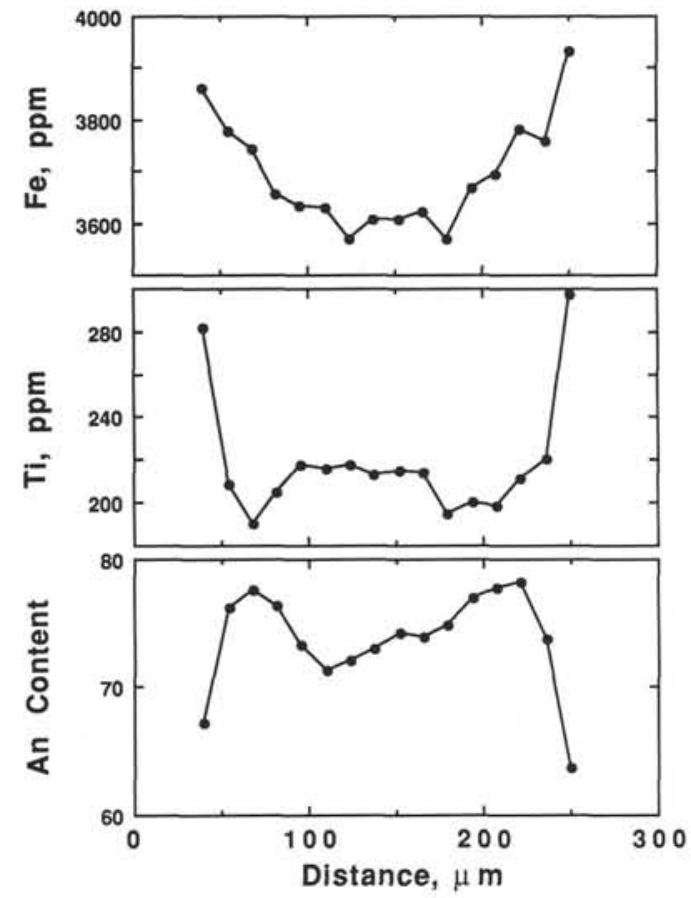

Figure 13. Zoning profile through sector-zoned crystal 18 (Fig. 12). Fe is low in the sodium rich core of the crystal and rises steadily toward the rims. This corresponds to an enrichment of $\mathrm{Fe}$ in the calcic prism sectors. In contrast, Ti shows a depletion in the these sectors.

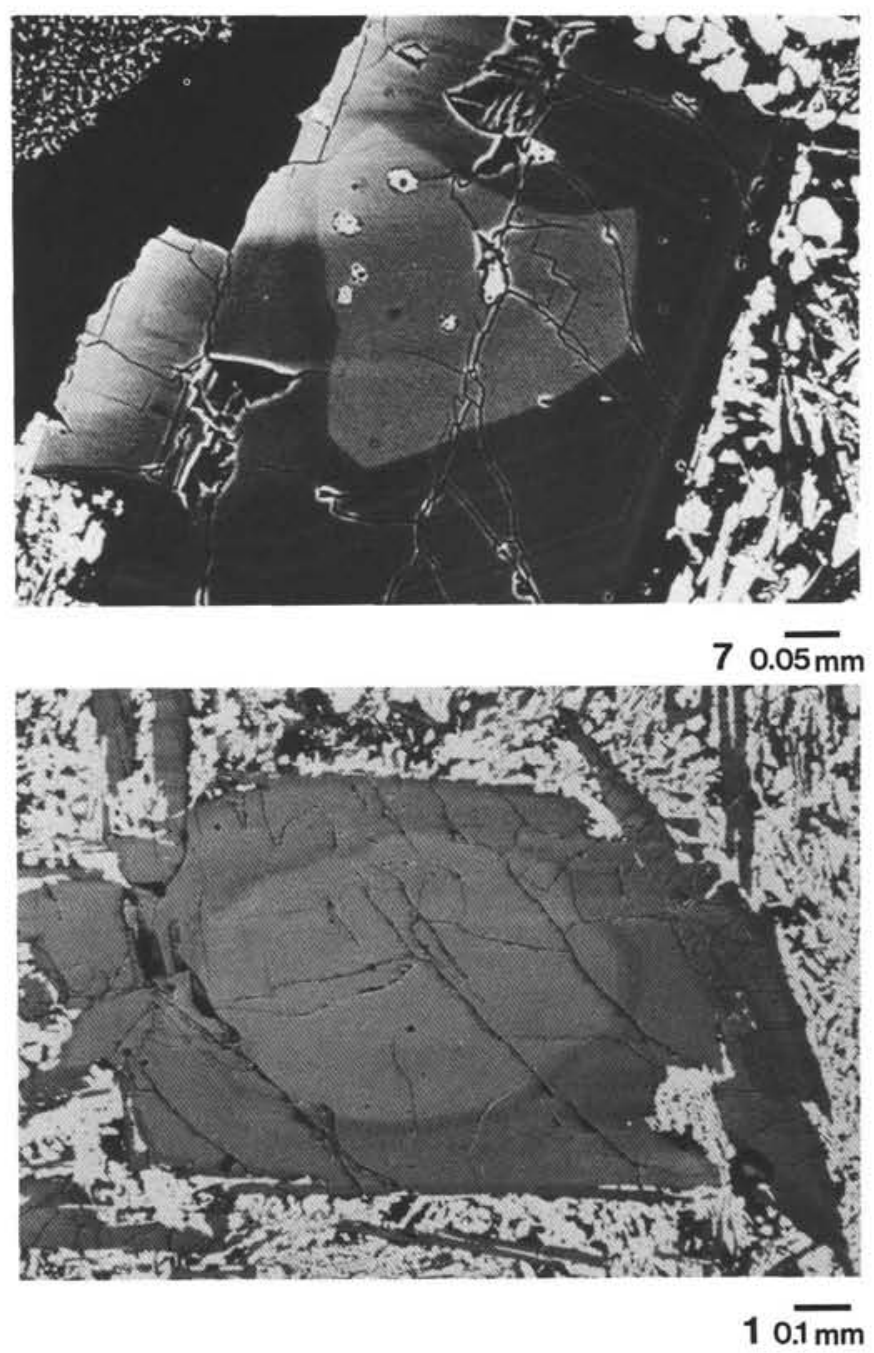

Figure 14. BEI of crystals with rounded and embayed calcic cores. 

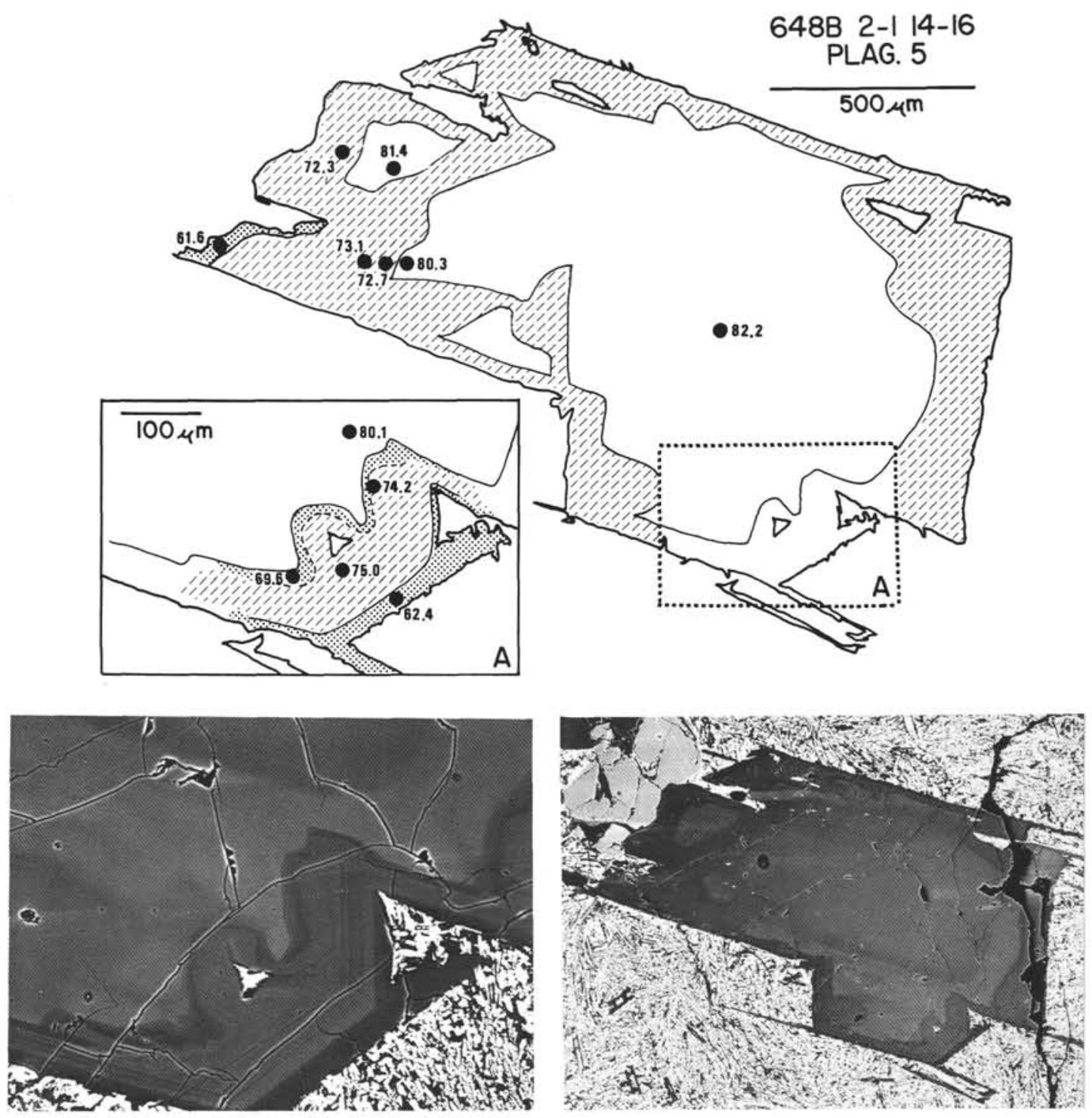

Figure 15. Sketch and BEI of crystal 11 showing an embayed calcic core $\left(\mathrm{An}_{82-80}\right)$. Zoning patterns depict major compositional zones, the darker the pattern, the more sodic the zone. Numbers give anorthite contents measured by electron microprobe. The inset shows an enlargement of the core-mantle boundary illustrating a sodic ribbon surrounding the embayed core. 

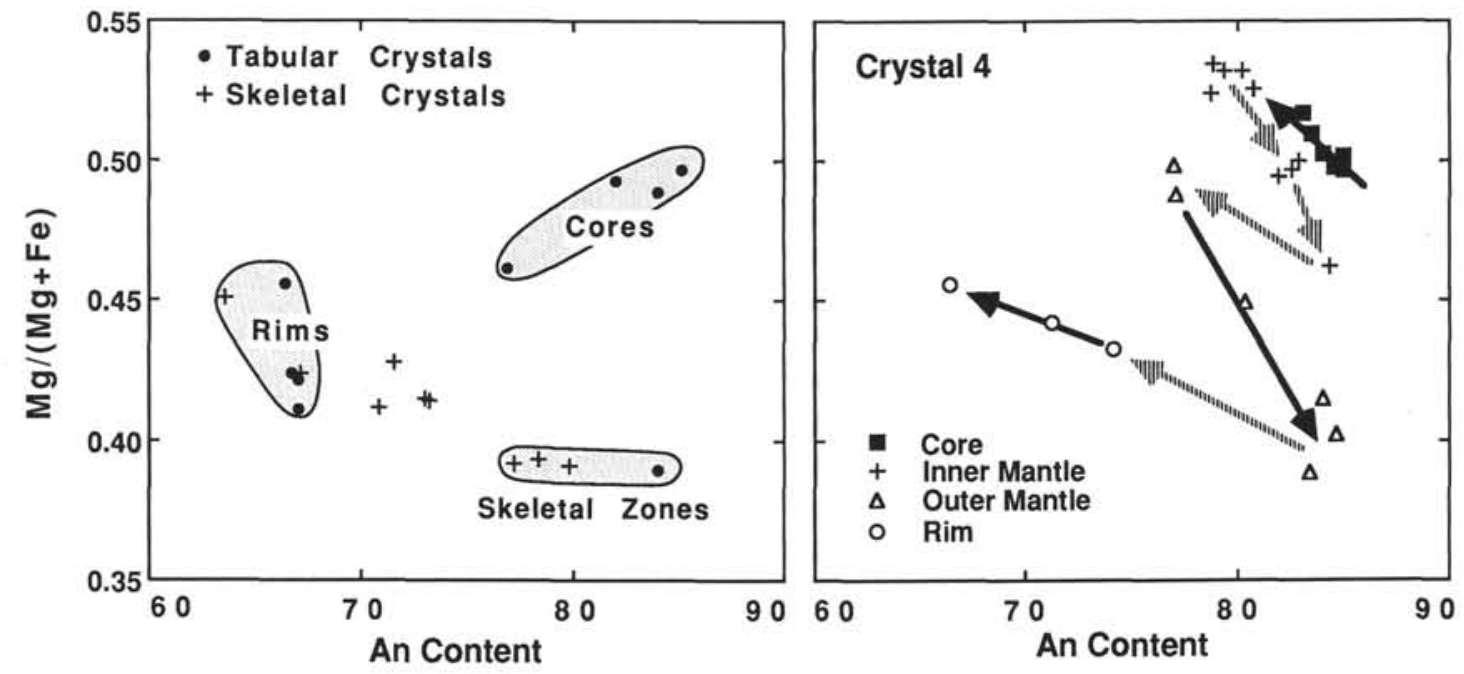

Figure 16. Magnesium number $(\mathrm{Mg} / \mathrm{Mg}+\mathrm{Fe})$ variations as a function of anorthite content in Hole $648 \mathrm{~B}$ plagioclase phenocrysts. Diagram on the left shows compositions in different types of zones: tabular cores, skeletal zones, and rims. The solid circle in the field for skeletal zones represents the complex mantle around the core of crystal 4. Note that equilibrium crystallization and stable crystal growth, represented by tabular cores and rims, leads to lower anorthite contents and lower magnesium numbers while skeletal crystal growth results in significant lowering of magnesium numbers at nearly constant anorthite contents. The diagram on the right shows variations in magnesium number vs. anorthite content in crystal 4. Arrows indicate the core-to-rim progression with solid arrows showing continual compositional variations and lighter arrows marking compositional jumps.

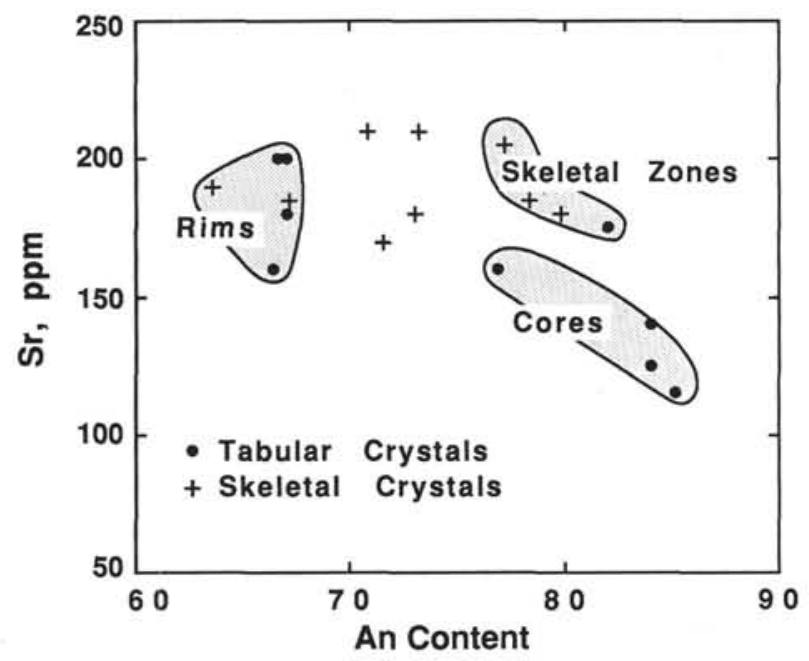

Figure 17. Strontium variations as a function of anorthite content in different types of zones. 
Table 5. Composition of parental melts from the Mid-Atlantic Ridge.

\begin{tabular}{|c|c|c|c|c|c|c|c|}
\hline & $648 \mathrm{~B}^{\mathrm{a}}$ & $648 \mathrm{~B}^{\mathrm{b}}$ & MAR $^{c}$ & $\underline{M A R}^{d}$ & Eam. $^{\mathrm{e}}$ & $\underline{\text { Icel. }}^{\mathrm{f}}$ & $\mathrm{IMg}$ \\
\hline Mg\#h & $0.52-0.56$ & 0.626 & 0.632 & 0.665 & 0.668 & 0.595 & 0.590 \\
\hline Ca\#政 & $0.74-0.79$ & 0.816 & 0.667 & 0.711 & 0.795 & 0.783 & 0.791 \\
\hline $\mathrm{K}_{2} \mathrm{O}(\mathrm{wt} \%)$ & $0.08-0.11$ & 0.04 & 0.10 & 0.07 & 0.08 & 0.04 & 0.05 \\
\hline $\mathrm{TiO}_{2}(\mathrm{wt} \%)$ & $1.0-1.3$ & 0.98 & 0.92 & 0.87 & 0.84 & 1.02 & 0.92 \\
\hline $\mathrm{Sr}(\mathrm{ppm})$ & $130-140$ & 90 & 127 & 114 & -- & -- & -. \\
\hline
\end{tabular}

a. Calculated melt composition in equilibrium with An82-78.

b. Calculated melt composition in equilibrium with An85.2.

c. Basalt (AII-78-3) from MAR $23^{\circ} \mathrm{N}$ (Bryan et al., 1981).

d. Basalt (CH21-20) from MAR $29^{\circ} \mathrm{N}$ (Bryan et al., 1981).

e. Basalt (AII-77-76-61) from Famous area (Bryan, 1979).

f. Basalt (HS773) from Iceland (Sigurdsson, 1981).

g. Basalt (TR139-18D-1) from Jan Mayen Ridge (Sigurdsson, 1981).

h. $\mathrm{Mg} \#=\mathrm{Mg} /(\mathrm{Mg}+\mathrm{Fe})$.

i. $\mathrm{Ca} \#=\mathrm{Ca} /(\mathrm{Ca}+\mathrm{Na})$. 